\title{
The Role of Prostaglandins in Allergic Lung Inflammation and Asthma
}

\author{
Dru Claar, M.D. [Resident in Internal Medicine], Tina V. Hartert, M.D., M.P.H. [Professor of \\ Medicine], and R. Stokes Peebles Jr., M.D. [Professor of Medicine] \\ Division of Allergy, Pulmonary, and Critical Care Medicine, Department of Medicine, Vanderbilt \\ University School of Medicine, Nashville, Tennessee
}

\begin{abstract}
Prostaglandins are products of the cyclooxygenase pathway of arachidonic acid metabolism. There are five primary prostaglandins, $\mathrm{PGD}_{2}, \mathrm{PGE}_{2}, \mathrm{PGF}_{2}, \mathrm{PGI}_{2}$, and thromboxane $\mathrm{B}_{2}$, all of which signal through distinct seven transmembrane, G-protein coupled receptors. Some prostaglandins may counteract the actions of others, or even the same prostaglandin may have opposing physiologic or immunologic effects, depending on the specific receptor through which it signals. In this review, we will examine the effects of cyclooxygenase activity and the various prostaglandins on allergic airway inflammation and physiology that is associated with asthma. We also highlight the potential therapeutic benefit of targeting prostaglandins in allergic lung inflammation and asthma based on basic science, animal model, and human studies.
\end{abstract}

Prostaglandins are lipids derived from plasma and nuclear membranes that are produced by the actions of cyclooxygenase (COX) enzymes in the arachidonic acid metabolic pathway. ${ }^{1}$ Prostaglandins were discovered in the mid-1930s in independent laboratories led by von Euler and Goldblatt, and initial studies focused on their effects on blood pressure and smooth muscle constriction. ${ }^{2 ; 3}$ One of the first publications that suggested prostaglandins had an important role in allergic disease was published by Piper and Vane in 1969. ${ }^{4}$ These investigators found that prostaglandin $(\mathrm{PG}) \mathrm{E}_{2}$ and $\mathrm{PGF}_{2 \mathrm{a}}$ were released during anaphylaxis of guinea pig lungs and their production could be blocked by low doses of aspirin and indomethacin. Subsequent to this discovery, myriad both pro- and anti-allergic effects have been attributed to prostaglandins. Early studies were hampered by the prostaglandin's short biologic half-lives, on the order of seconds to a few minutes. However, the discoveries of how prostaglandins regulate allergic inflammation have accelerated in the last 15 years. This has largely been a result of the proliferation of transgenic mouse models in which either a prostaglandin receptor gene or synthase has been knocked out or overexpressed. In addition, the development of prostaglandin agonists that have longer biologic activity than a native prostaglandin, in addition to specific receptor antagonists, have greatly advanced both human and animal studies in our knowledge of how these regulate allergic diseases. In this article, we will review the pathways of prostaglandin generation, examine studies that confirm the presence of these products in allergic inflammatory states, and discuss in vivo

Address reprint requests to: Stokes Peebles, M.D., T-1217 MCN Vanderbilt University Medical Center, Nashville, TN 37232-2650, Telephone: 615-322-3412; Fax: 615-343-7448, stokes.peebles@ vanderbilt.edu. 
intervention studies in humans and recent murine studies which elucidate the activity of these mediators in the pathogenesis of allergic disease. Based on this data, we speculate on individual prostaglandins as potential therapeutic targets in the treatment of allergic diseases and asthma.

\section{Generation of prostaglandins by phospholipase $A_{2}$}

Arachidonic acid is the precursor for the synthesis of all prostaglandins and leukotrienes. These products of arachidonic acid metabolism are together known as eicosanoids because the Greek word for twenty is "eikosi", the number of carbon atoms in arachidonic acid. There are several phospholipases $\mathrm{A}_{2}\left(\mathrm{PLA}_{2}\right)$ enzymes that hydrolyze fatty acids at the sn-2 position of membrane phospholipids, resulting in the formation of free fatty acids, including arachidonic acid. ${ }^{5}$ There are six classes of $\mathrm{PLA}_{2} \mathrm{~s}$, secretory $\mathrm{PLA}_{2} \mathrm{~s}$ ( $\left.\mathrm{sPLA}_{2}\right)$, cytosolic $\mathrm{PLA}_{2} \mathrm{~s}\left(\mathrm{cPLA}_{2}\right), \mathrm{Ca}^{2+}$ independent $\mathrm{PLA}_{2}\left(\mathrm{PLA}_{2}\right)$, platelet-activating factor acetylhydrolases (PAF-AH), lysosomal $\mathrm{PLA}_{2} \mathrm{~S}$, and adipose-specific $\mathrm{PLA}_{2} .{ }^{5}$ The $\mathrm{PLA}_{2} \mathrm{~S}$ are classified based upon the catalytic mechanism of the individual PLA 2 , in addition to their functional and structural properties. Sixteen groups of $\mathrm{PLA}_{2}$ have now been identified, however, the groups that lead to lipid mediator generation are limited to group IIA, group IVA, group V, group $\mathrm{VI}$ and group $\mathrm{X} .5 ; 6$

The sPLA $_{2}$ are small enzymes (14-18 kDa) secreted from their cellular source. ${ }^{5}$ After secretion, the $\mathrm{SPLA}_{2} \mathrm{~s}$ participate in either paracrine or autocrine generation of arachidonic acid from the outer leaflet of plasma membranes. Group IIA $\mathrm{SPLA}_{2}$ is critical in the generation of lysophosphatidyl choline for synthesis of LPA. ${ }^{5}$ Group V sPLA 2 has an important role in the development of allergic airway inflammation in mice. For instance, in the house dust mite model, group $\mathrm{V} \mathrm{sPLA}_{2}$-deficient mice had markedly decreased pulmonary inflammation and goblet cell metaplasia in comparison to wild type (WT) mice, likely a result of reduced antigen processing and maturation of antigen presenting cells. ${ }^{7}$ Mice deficient in group X sPLA 2 had decreased bronchial inflammation, production of lung Th2 cytokines, airway remodeling, and concentrations of several lipid mediators in a model of ovalbumin (OVA)-induced airway disease. The importance of human group X sPLA $\mathrm{S}_{2}$ to the allergic phenotype was verified when human group $\mathrm{X} \mathrm{sPLA}_{2}$ was knocked-in to mice deficient in murine group $\mathrm{X} \mathrm{sPLA} 2 .{ }^{8}$ Group X sPLA2 is abundantly produced by the airway epithelium of asthmatic subjects and may have a critical role in asthma provoked by exercise and in the severe asthma phenotype by providing arachidonic acid for the rapid transformation to cysteinyl LTs. ${ }^{9-11}$

The $\mathrm{cPLA}_{2}$ are present in the cytosol and are larger than the $\mathrm{PPLA}_{2}(61-114 \mathrm{kDa}) .^{5}$ There are six subgroups (denoted A-F) of $\mathrm{CPLA}_{2}$ enzymes in group IV. This enzyme may have a role in asthma pathogenesis as group IVA cPLA $_{2}$ was over-expressed in patients with persistent asthma. ${ }^{12}$

The group VI PLA 2 are $\mathrm{Ca}^{2+}$ independent and termed iPLA $2 .{ }^{5}$ Group VIA and group VIB $\mathrm{iPLA}_{2}$ act to generate arachidonic acid release for eicosanoid production. Group VIA is important in glycerophospholipid remodeling, protein expression, acetylcholine-modulated endothelium-dependent relaxation of vessels, apoptosis, and lymphocyte proliferation. 
Lastly, there are two groups of platelet-activating factor acetylhydrolases (PAF-AH), classified as groups VII and VIII. While PAF-AH is not known to participate in eicosanoid formation, inactivation of PAF by PAF-AH may have a protective role against anaphylaxis as persons with lower levels of PAH-AF had more severe manifestations of anaphylaxis than those with higher levels of PAF-AH. ${ }^{13}$

Thus, the PLA 2 enzymes are critical for the generation of arachidonic acid from membrane phospholipids.

\section{CYCLOOXYGENASE PATHWAY}

Arachidonic acid can be oxidatively metabolized by both the COX and lipoxygenase (LO) pathways, but the COX pathway is the primary focus of this review. ${ }^{14} \mathrm{COX}$ catalyzes two reactions, an initial cyclooxygenase reaction resulting in the insertion of two oxygen molecules into arachidonic acid to produce prostaglandin $(\mathrm{PG}) \mathrm{G}_{2}$, with a subsequent endoperoxidase reaction that reduces $\mathrm{PGG}_{2}$ to $\mathrm{PGH}_{2}$ (Figure 1). $\mathrm{PGH}_{2}$ is the precursor for the prostanoids $\mathrm{PGD}_{2}, \mathrm{PGE}_{2}, \mathrm{PGF}_{2 \alpha}, \mathrm{PGI}_{2}$, and thromboxane $\mathrm{A}_{2}\left(\mathrm{TXA}_{2}\right)$. Each of the prostanoids is produced by tissue specific enzymes and isomerases that will be further discussed later. Two COX enzymes, COX-1 and COX-2, are functional in humans. A third cyclooxygenase enzyme, COX-3, is encoded by the COX-1 gene, but has an intron that is not retained in COX-1 and is not believed to be functional in humans. COX-1 and COX-2 are products of separate genes and have different biologic functions based on their divergent temporal and tissue-specific expression. ${ }^{14}$ The human COX-1 gene is present on chromosome 9 and is constitutively expressed in most tissues. COX-1 can be induced in specific instances and is thought to participate in homeostatic prostanoid synthesis. ${ }^{15} \mathrm{In}$ contrast, COX-2 expression is usually induced and the induction is transient. The human COX-2 gene is located on chromosome 1. COX-2 expression is induced by the cytokines interleukin (IL)-1, IL-2, and TNF, as well as by lipopolysaccharide (LPS) produced by Gram-negative bacteria. ${ }^{15}$ While COX-2 is primarily considered to be an inducible enzyme, it is also constitutively expressed in cultured human lung epithelial cells, cortical thick ascending limb of the kidney, pancreatic islet cells, and in human gastric carcinoma. ${ }^{16-18}$ The ability of nonsteroidal anti-inflammatory drugs to inhibit COX-2 activity is likely their major therapeutic effect, while the inhibition of COX-1 may result in some of their undesired side effects. ${ }^{15}$ However, there are instances where inhibition of COX-2 may be harmful. For instance, there was an increase in cardiovascular disease resulted from medications that specifically inhibited COX-2, likely as a result $\mathrm{PGI}_{2}$, inhibition, while the COX-1 product $\mathrm{TXA}_{2}$ was unaffected. ${ }^{19}$

\section{Human studies of the COX pathway in allergic inflammation-Several}

investigators have examined COX-2 expression in the airway to help discern the role of this enzyme in allergic diseases; however, the results have been contradictory. For instance, one study reported a fourfold amplification in bronchial epithelial COX-2 immunostaining in asthmatic subjects compared to healthy controls; ${ }^{20}$ in contrast, another reported no difference in the level of immunostaining in asthmatics, chronic bronchitics, or controls who had no lung disease. ${ }^{21}$ Corticosteroids may decrease COX-2 mRNA expression and immunoreactive protein, as both of these were increased in the airway epithelium of 
asthmatics that had not been treated with corticosteroids compared with non-asthmatic controls. Possibly supporting this notion, corticosteroid-treated asthmatics had decreased COX-2 expression compared to non-treated asthmatics. ${ }^{22}$ The relationship between the cytokines implicated in the allergic response and COX-2 expression is complex. IL-4 and IL-13 inhibited $\mathrm{PGE}_{2}$ production in bronchial epithelial cells by reducing both COX-2 and microsomal PGE synthase (mPGES) via JAK1 and STAT6 signaling. ${ }^{23}$ Therefore, in persons with asthma, increased TNF expression might induce COX-2, while IL-4 and IL-13 might reduce COX-2 expression. Therefore, corticosteroids may modulate COX-2 expression by indirectly reducing IL-4 and IL-13, while in contrast, TNF in the asthmatic airway may induce COX-2. This concept is supported by in vitro data in which COX-2 immunoreactivity in cultured airway epithelial cells was decreased by corticosteroid treatment. ${ }^{24}$ Corticosteroids reduced basal and bradykinin-induced levels of $\mathrm{PGE}_{2}$ in airway epithelial cells, suggesting that $\mathrm{COX}-2$ is the primary producer of $\mathrm{PGE}_{2}$ in airway epithelium. ${ }^{24} \mathrm{PGE}_{2}$, as will be discussed later in this review, has potent anti-inflammatory properties when it signals through the $\mathrm{EP}_{2}$ receptor. Downregulation of COX-2 by corticosteroids may decrease $\mathrm{PGE}_{2}$ production, thus perhaps removing the brake $\mathrm{PGE}_{2}$ exerts on inflammation. This is a possible mechanism by which corticosteroids fail to reduce inflammation in certain patient populations and might lead to corticosteroid resistant asthma. There is controversy over the in vivo effect of corticosteroids on COX-1 and COX-2 expression in nasal polyp tissue. For instance, prednisone increased COX-2 mRNA expression in polyp tissue after two weeks of therapy, yet there was no effect on COX-1 mRNA expression. ${ }^{25}$ However, topical glucocorticoids significantly reduced the number of COX-1 expressing nasal polyp cells, yet had no effect on COX-2 expressing cells in nasal polyps. ${ }^{26}$

In addition to structural cells in the airway, COX-1 and COX-2 mRNA is present in resting human $\mathrm{T}$ lymphocytes. ${ }^{27} \mathrm{~T}$ cell activation did not alter COX-1 expression in $\mathrm{T}$ cells, yet $\mathrm{T}$ cell stimulation increased COX-2 mRNA levels with increased COX-2 protein and cyclooxygenase activity. ${ }^{27}$ Macrophages, endothelial cells, airway epithelial cells, airway smooth muscle cells, mast cells, eosinophils, and airway fibroblasts have the potential for inducible COX-2 expression. ${ }^{20 ; 28}$ Therefore, COX expression is present in both resident airway cells and adaptive immune cells.

COX products are increased as a result of allergic inflammation. There is a significant increase in prostanoids in the bronchoalveolar (BAL) fluid of allergic asthmatics compared to healthy nonasthmatic controls. In addition, allergic antigen challenge of the airways further increases prostanoid production. There was a 12- to 22-fold increase in BAL fluid $\mathrm{PGD}_{2}$ and $\mathrm{PGF}_{2 \mathrm{a}}$ levels in asthmatics compared to nonallergic subjects, and a 10-fold increase in these same metabolites in allergic asthmatics compared to nonasthmatic subjects who had allergic rhinitis. ${ }^{29}$ Segmental allergen challenge, a process where allergen is instilled to a segment of the lung via bronchoscopy, resulted in a 17- to 208-fold increase in the levels of $\mathrm{PGD}_{2}$, thromboxane $(\mathrm{Tx}) \mathrm{B}_{2}$, and 6-keto-PGF $\mathrm{Pa}_{1 \mathrm{a}}$, a $\mathrm{PGI}_{2}$ metabolite in allergic asthmatics. ${ }^{30}$ When these subjects were treated for three days with prednisone prior to segmental allergen challenge, there was no change in the BAL fluid prostanoid concentrations, suggesting that corticosteroids did not reduce COX pathway activation 
resulting from an allergic inflammatory stimulus, ${ }^{31}$ supporting the findings in patients with nasal polyps that were treated with prednisone discussed in the preceding paragraph.

Investigations blocking the COX pathway with medications such as indomethacin, which inhibits both COX-1 and COX-2, have been performed to determine the impact of COX products on allergen-induced airway inflammation and physiologic changes. Indomethacin did not change lung function before allergen challenge in either subjects with allergic asthma or allergic rhinitis that did not have asthma. ${ }^{32}$ However, indomethacin treatment decreased the forced expiratory volume in one second $\left(\mathrm{FEV}_{1}\right)$ and specific airway conductance in nonasthmatic subjects with allergic rhinitis in response to inhaled allergen challenge. ${ }^{32}$ Indomethacin administration prior to allergen challenge caused a small, but significant reduction in specific airway conductance in subjects with allergic asthmatic subjects compared to placebo; however, this non-specific COX inhibitor did not alter allergen-induced alterations in $\mathrm{FEV}_{1} \cdot{ }^{32}$ Indomethacin treatment also neither significantly changed airway responsiveness to histamine nor the immediate or late phase pulmonary response to allergen challenge in allergic asthmatics. ${ }^{33 ; 34}$ In subjects with exercise-induced asthma, indomethacin did not change bronchoconstriction after exercise, but prevented refractoriness after exercise. ${ }^{35}$ The apparent complex effect of COX inhibition on lung function reflects the diversity of the individual prostanoids and the receptors with which they signal (see below). It is clear that some prostanoids may counteract the actions of others, or even the same prostanoid may have opposing physiologic or immunologic effects, depending on the specific receptor through which it signals.

Mouse studies of the COX pathway in allergic inflammation-Transgenic mice have been created with targeted deletions of the COX-1 and COX-2 genes and then subjected to models of OVA sensitization and challenge. COX-1 knock out (KO) mice that were OVA-sensitized and challenged had augmented lung eosinophilia, increased serum IgE levels, heightened airway responsiveness, greater numbers of $\mathrm{CD} 4^{+}$and $\mathrm{CD} 8^{+} \mathrm{T}$ cells, amplified levels of Th2 cytokines, and exaggerated concentrations of eotaxin and thymusand activation-regulated chemokine (TARC, CCL17) compared to both COX-2 KO and WT control mice. ${ }^{36 ; 37}$ These results suggest that COX-1-derived prostanoids are critical in maintaining homeostasis during allergen-induced airway inflammation. These studies which show that COX-1 inhibition increases allergic airway inflammation and airway responsiveness would suggest that that COX-1 overexpression might decrease allergeninduced inflammation and inhibit airway responsiveness. However, while airway epithelial cell targeted COX-1 overexpression reduced basal airway responsiveness, there was no effect on allergic inflammation. ${ }^{38}$ The role of COX-2 in allergic airway inflammation and bronchomotor tone has also been examined in animal models. One report indicated that COX-2 KO mice on a C57BL/6 genetic background had augmented serum IgE levels, vascular cell adhesion molecule-1 (VCAM-1) and intercellular adhesion molecule-1 (ICAM-1) levels compared to WT mice, while there were no differences in airway eosinophils or airway responsiveness. ${ }^{36 ; 37}$ Supporting this result, other investigators reported that COX-2 $\mathrm{KO}$ mice, also on a C57BL/6 background, had increased allergeninduced lung eosinophilia as compared to WT mice. ${ }^{39}$ 
Studies employing pharmacologic inhibition complement and, in general, support the transgenic mouse models. WT BALB/c mice treated with indomethacin in the drinking water during both OVA sensitization and challenge had augmented Th2 cytokines in the lungs, greater pulmonary eosinophilia, and heightened airway responsiveness to methacholine compared to mice treated with vehicle. ${ }^{40}$ While BAL cysteinyl leukotriene levels were increased as a result of indomethacin treatment, 5-LO KO mice on a 129 genetic background, which could therefore not generate leukotrienes, also had augmented allergeninduced inflammation with indomethacin treatment. These results essentially rule out enhanced leukotriene production as a cause for the exaggerated inflammatory response in the indomethacin-treated mice. ${ }^{41}$ The augmented allergic inflammation with indomethacin treatment was dependent upon $\mathrm{CD} 4^{+}$cells; however, it was independent of IL-4, IL-4 receptor alpha signaling, and STAT6, factors important in the Th2 signaling pathway. ${ }^{42}$ This augmented allergic phenotype was not specific to indomethacin, as both COX-1 and COX-2 inhibitors independently augmented allergen-induced lung levels of IL-13 and methacholine responsiveness compared to vehicle-treated mice. ${ }^{43} \mathrm{COX}-2$ inhibition in a mouse model of atopic dermatitis that was induced epicutaneous OVA sensitization resulted in augmented eosinophil skin infiltration, increased total and antigen specific IgE, and a systemic Th2 response to antigen. ${ }^{44}$ The role of COX-2 in modulating airway tone has also been investigated in guinea pig models. COX-2 was induced during allergic inflammation in guinea pigs and the COX-2 inhibitor celecoxib significantly inhibited allergen-induced bronchoconstriction and release of COX products. ${ }^{45 ; 46}$ Further, $\mathrm{PGE}_{2}$-induced contraction was abolished by COX-2 inhibition. ${ }^{47}$ Therefore, a number of studies reveal that COX inhibition during the development of allergic disease increased allergen-induced inflammation and airway responsiveness, implying that a COX product restrains allergic inflammation and possibly could be a therapeutic target for the treatment of allergic diseases such as asthma and atopic dermatitis.

It is important to note that in most of these mouse models of allergen-induced inflammation, COX was inhibited from the initial stage of antigen presentation throughout all allergen challenges. In human studies using indomethacin, COX inhibition transpired only during allergen challenge, long after initial antigen presentation and after the regulatory elements of allergic inflammation in the lung had been set in place. It is also important to note there is divergence between mouse and human studies in regard to airway physiology. For instance, while $\mathrm{PGD}_{2}$ causes bronchoconstriction in humans, this prostanoids fails to constrict mouse airways. ${ }^{48}$ Therefore, animal models of allergic lung disease, in which COX activity is inhibited either pharmacologically or by targeted gene deletion, may be better suited to identify the immunologic function of prostanoids, rather than the direct effects on end-organ physiology that are more often investigated in human studies.

\section{Individual Prostanoids}

\section{Prostaglandin $\mathrm{D}_{2}$}

$\mathrm{PGD}_{2}$ is the major mast cell-derived prostanoid and is elaborated in nanogram quantities in these cells in response to IgE-mediated activation. ${ }^{14}$ Eosinophils also synthesize $\mathrm{PGD}_{2}{ }^{49}$ There are two different enzymes that produce $\mathrm{PGD}_{2}$, hematopoietic- and lipocalin- $\mathrm{PGD}_{2}$ 
synthases (H-PGDS and L-PGDS, respectively); H-PGDS produces $\mathrm{PGD}_{2}$ production in mast cells and other hematopoietic cells. In contrast, L-PGDS is present in oligodendrocytes, the choroid plexus, organs of the male genital tract, leptomeninges, and in humans and monkeys hearts. L-PGDS gene expression in the central nervous system can be regulated by glucocorticoid, thyroid, and estrogen hormones, while L-PGDS expression in the heart is regulated by estrogen. H-PGDS is expressed at high levels in human placenta, lung, adipose tissue, and fetal liver, while it is expressed at lower levels in the bone marrow, heart, lymph nodes, and appendix. H-PGDS is expressed not only in mast cells, but also in CD4 ${ }^{+} \mathrm{Th} 2$ lymphocytes, $\mathrm{CD} 8^{+} \mathrm{Tc} 2$ cells, megakaryocytes, dendritic cells (DCs), histiocytes, and Kupffer cells. $\mathrm{PGD}_{2}$ can be metabolized to $\mathrm{PGF}_{2 a}, 9 a, 11 \beta-\mathrm{PGF}_{2}$ (the stereoisomer of $\mathrm{PGF}_{2 \mathrm{a}}$ ), and the $\mathrm{J}$ series of prostanoids which includes $\mathrm{PGJ}_{2}, \Delta^{12}-\mathrm{PGJ}_{2}$, and $15 \mathrm{~d}-\mathrm{PGJ}_{2} \cdot{ }^{14}$

All of the prostanoids signal through distinct seven transmembrane, G-protein coupled receptors (GPCRs). The receptors through which $\mathrm{PGD}_{2}$ signals are termed $\mathrm{DP}_{1}$ and $\mathrm{DP}_{2}$ (Figure 1). ${ }^{14} \mathrm{DP}_{1}$ is expressed on mucus-secreting goblet cells in the nasal and colonic mucosa, nasal serous glands, vascular endothelium, Th2 cells, DCs, basophils, and eosinophils. $\mathrm{DP}_{1}$ stimulation activates adenylate cyclase, leading to an intracellular increase in cAMP levels and protein kinase $\mathrm{A}$ activity. $\mathrm{DP}_{2}$ is also known as chemoattractant receptor-like molecule expressed on Th2 cells (CRTH2). In addition to $\mathrm{PGD}_{2}$, other $\mathrm{DP}_{2}$ agonists include $\Delta^{12}$ PGJ $_{2} ; 15$-deoxy- $\Delta^{12,14} \mathrm{PGJ}_{2}\left(15 \mathrm{~d}-\mathrm{PGJ}_{2}\right) ; 13$, 15-dihydro-15-keto- $\mathrm{PGD}_{2}$; 11-dehydro- $\mathrm{TXB}_{2}$; and the $\mathrm{COX}$ inhibitor indomethacin. ${ }^{50 ; 51} \mathrm{DP}_{2}$ is expressed on immune cells such as eosinophils, basophils, and the $\mathrm{T}$ cell subsets $\mathrm{CD} 4^{+} \mathrm{Th} 2$ and $\mathrm{CD} 8^{+} \mathrm{Tc} 2$ cells. $\mathrm{PGD}_{2}$ induces chemotaxis in each of the immune cells in a $\mathrm{DP}_{2}$-dependent manner. $\mathrm{DP}_{2}$ is preferentially expressed by IL- $4^{+} / \mathrm{IL}-13^{+} \mathrm{T}$ cells compared to IFN- $\gamma^{+} \mathrm{T}$ cells in the BAL fluid of subjects with asthmatic. ${ }^{52} \mathrm{DP}_{2}$ signaling in eosinophils increases their release from bone marrow, stimulates their respiratory burst, augments the chemotactic response to other chemokines such as eotaxin, and primes them for degranulation. Further, $\mathrm{DP}_{2}$ signaling increased microvascular permeability, depletion of goblet cells, and constricted coronary arteries. In opposition to $\mathrm{DP}_{1}$ signaling, activation of $\mathrm{DP}_{2}$ decreased intracellular cAMP. ${ }^{14}$ Therefore, $\mathrm{PGD}_{2}$ signaling through $\mathrm{DP}_{2}$, through suppression of cAMP, would be predicted to facilitate allergic inflammation through its effect on chemotaxis and mediator release by effector cells. $\mathrm{PGD}_{2}$ and its immediate metabolite, $9 \mathrm{a}, 11 \beta-\mathrm{PGF}_{2}$ contracts smooth muscle and this is presumed to be predominantly mediated through the thromboxane TP receptor. ${ }^{53 ; 54}$

Human studies of $\mathrm{PGD}_{2}$ in allergic inflammation-Inhalation challenge of human allergic asthmatic subjects with allergen to which the subjects were sensitized increased $\mathrm{PGD}_{2}$ in BAL fluid. ${ }^{55} \mathrm{PGD}_{2}$ was also increased in the nasal lavage from subjects with allergic rhinitis, ${ }^{56}$ in tears from persons experiencing allergic conjunctivitis, ${ }^{57}$ and in the fluid obtained from experimentally produced skin blisters in patients with late phase reactions of the skin. ${ }^{58}$ In asthmatic subjects, the stable urinary $\mathrm{PGD}_{2}$ metabolite, $9 \mathrm{a}, 11 \beta$ $\mathrm{PGF}_{2}$, was not altered by treatment with the COX-2 specific inhibitor celecoxib for three days, suggesting that $\mathrm{PGD}_{2}$ is predominantly produced by the activity of COX-1. ${ }^{59} \mathrm{In}$ contrast, aspirin challenge of individuals with aspirin-exacerbated respiratory disease did not diminish $\mathrm{PGD}_{2}$ concentration in $\mathrm{BAL}$ fluids. $\mathrm{PGD}_{2}$ is a potent bronchoconstrictor and 
vasodilator, and potentiated airway responsiveness ${ }^{60}$ Intranasal administration of $\mathrm{PGD}_{2}$ increased nasal resistance 10-fold more potently than histamine and 100-fold greater than bradykinin. ${ }^{61} \mathrm{PGD}_{2}$ administration increased vascular leakage in the conjunctiva and skin, ${ }^{62}$ and resulted in eosinophil influx in the conjunctiva ${ }^{63}$ and trachea, ${ }^{64}$ implicating it as having a pathogenic role in allergic disease. The vascular effects of $\mathrm{PGD}_{2}$ mostly reflect dilation mediated by $\mathrm{DP}_{1}$, whereas recruitment of effector cells is more likely to reflect chemotaxis via $\mathrm{DP}_{2} \cdot{ }^{50 ; 65}$ These data strongly suggest that $\mathrm{PGD}_{2}$ is involved in the pathogenesis of allergic diseases; however, there are no published studies that show that a specific $\mathrm{PGD}_{2}$ antagonist had a beneficial effect in the treatment of these disorders, despite the development of multiple $\mathrm{DP}_{1}$ and $\mathrm{DP}_{2}$ antagonists. Therefore, it is still not clear if $\mathrm{PGD}_{2}$ has a mechanistic role in allergen-induced inflammation. In regard to smooth muscle contraction by PGD $_{2}$ released upon allergen exposure, TP receptor antagonists such as GR32191 partially antagonized the early bronchoconstrictor response, with other constrictor mediators, such as histamine and $\mathrm{LTC}_{4} / \mathrm{LTD}_{4}$, contributing to make up the difference. ${ }^{66}$

The therapeutic effects of $\mathrm{DP}_{2}$ antagonists have now also been examined in humans with asthma. In a randomized, double-blind, placebo-controlled trial in subjects with moderatepersistent asthma, the $\mathrm{DP}_{2}$ antagonist OC000459 significantly improved both quality of life and night-time symptom score. ${ }^{67}$ There was also a significant reduction in geometric mean sputum eosinophil count in the $\mathrm{DP}_{2}$ antagonist group compared to pre-treatment baseline, although this decrease was not significant compared to the placebo-treated group. Additional studies will be important to confirm the clinical usefulness $\mathrm{DP}_{2}$ antagonism in asthma.

Mouse studies of $\mathrm{PGD}_{2}$ in allergic inflammation-Studies in mice suggest a complex role for $\mathrm{PGD}_{2}$ in experimental allergic disease. ${ }^{68}$ Mice that overexpress L-PGDS had greater BAL fluid levels of Th2 cytokines, eotaxin, eosinophils, and lymphocytes after allergen sensitization and challenge compared to nontransgenic littermates. ${ }^{69}$ Aerosolized $\mathrm{PGD}_{2}$ administered one day prior to inhalational challenge with low-dose antigen increased BAL eosinophils, lymphocytes, and macrophages, in addition to IL-4 and IL-5, in sensitized mice. ${ }^{70}$ Such findings imply that $\mathrm{PGD}_{2}$ augments pulmonary $\mathrm{Th} 2$ responses.

Mouse studies exploring the role of $\mathrm{DP}_{1}$ in allergic inflammation have been contradictory. Allergen sensitized and challenged $\mathrm{DP}_{1} \mathrm{KO}$ mice had significantly reduced airway responsiveness and BAL concentrations of IL-4, IL-5, and IL-13 compared to WT mice, while there was no difference in the BAL levels of IFN $-\gamma .{ }^{68}$ In addition, $\mathrm{DP}_{1} \mathrm{KO}$ mice had decreased BAL eosinophils and lymphocytes compared to WT mice, implying that $\mathrm{DP}_{1}$ signaling was important in the full expression of allergic inflammation. ${ }^{68}$ However, the $\mathrm{DP}_{1}$ agonist BW245C inhibited lung DC function, including the ability of DCs to stimulate T cell proliferation and DC migration to the lungs. ${ }^{71 ; 72} \mathrm{BW} 245 \mathrm{C}$-treated mice, or mice receiving adoptively transferred $\mathrm{DP}_{1}$-treated DCs, had an increase in the number of Foxp3 $3^{+} \mathrm{CD}^{+}$ regulatory T cells, which suppressed inflammation in an IL-10-dependent mechanism. ${ }^{72}$ The reduction in allergic inflammation caused by the $\mathrm{DP}_{1}$ agonist via diminished DC function was regulated via cyclic AMP-dependent protein kinase A. ${ }^{72}$ In addition, chimeric mice that lacked $\mathrm{DP}_{1}$ expression on hematopoietic cells had increased airway inflammation following allergen challenge, suggesting an important homeostatic role of $\mathrm{DP}_{1}$ and endogenous $\mathrm{PGD}_{2}{ }^{72}$ Taken together, these results suggest that $\mathrm{DP}_{1}$ signaling facilitates 
effector responses through structural cells, yet inhibits DC function at the sensitization phase to reduce allergic inflammatory process.

Studies in different species support the concept that signaling through $\mathrm{DP}_{2}$ augments allergic inflammation. A DP 2 receptor antagonist, AM211, reduced OVA-induced airway eosinophilia in guinea pigs, while inhibiting the number of sneezes mice experienced following intranasal allergen challenge. ${ }^{73}$ In addition, a different $\mathrm{DP}_{2}$ antagonist, MK-7246, reduced antigen-induced late phase bronchoconstriction and airway responsiveness in sheep, while inhibiting antigen-induced eosinophilia in both sheep and monkeys. ${ }^{74}$ Lastly, an oral, potently selective alkynylphenoxyacetic acid $\mathrm{DP}_{2}$ antagonist reduced OVA-induced airway eosinophilia in mice. ${ }^{75}$ These studies support that $\mathrm{PGD}_{2}$ signaling through $\mathrm{DP}_{2}$ increases allergic inflammation, and inhibiting receptor signaling blunts inflammatory responses in animals.

\section{Prostaglandin $\mathrm{E}_{2}$}

$\mathrm{PGH}_{2}$ can be metabolized to $\mathrm{PGE}_{2}$ by three distinct enzymes, microsomal PGE synthase-1 (mPGES-1), mPGES-2, and cytosolic PGE synthase (cPGES). ${ }^{14}$ mPGES-1 is membraneassociated, localized to the perinuclear area, has a trimeric structure, and is glutathionedependent. $\mathrm{PGE}_{2}$ production was substantially greater in cells co-transfected with both mPGES- 1 and COX-2, suggesting that mPGE-2 preferentially couples with COX-2 to immediately generate $\mathrm{PGE}_{2}$ when COX-2 is active. mPGES-1 metabolizes $\mathrm{PGH}_{2}$ produced from $\mathrm{COX}-1$, but required exogenous administration of arachidonic acid. For instance, arachidonic acid generated by mast cell group IVA cPLA 2 led to $\mathrm{PGE}_{2}$ production by mouse fibroblast mPGES-1. ${ }^{76}$ The expression of cPGES was predominantly constitutive and was not induced by inflammatory stimuli. ${ }^{51 ; 77}$ Compared to mPGES-1, cPGES coupled more efficiently with COX-1 than with COX-2 for $\mathrm{PGE}_{2}$ generation. These results suggest that $\mathrm{cPGE}_{2}$ may provide $\mathrm{PGE}_{2}$ essential for cellular homeostasis, while mPGES-1 KO mice had significantly decreased basal $\mathrm{PGE}_{2}$ production in most organs. A recent study reported that mPGES-1 activity is inhibited in transformed cell lines by cysteinyl leukotriene receptor-1 antagonists $;{ }^{78}$ however, this has not been confirmed either in primary cells or in vivo. Studies in KO mice do not support that either cPGES or mPGES-2 are important PGESs enzymes in vivo. cPGES is localized to the cytosol and while there was evidence that it translocated from the cytosol to the nuclear membrane to assemble with COX-1 in $\mathrm{PGE}_{2}$ production, there seems that $\mathrm{CPGES}$ has a slight preference to interact with COX-2. ${ }^{79}$ Dexamethasone decreased cPGES activation. ${ }^{79}$ mPGES- 2 is expressed constitutively in many cells and tissues. ${ }^{79}$ In transfected cells, mPGES-2 uses $\mathrm{PGH}_{2}$ derived from COX-1 and COX-2 with equal efficiency. Local $\mathrm{PGE}_{2}$ concentrations are regulated by COX-2 driven synthesis and $\mathrm{PGE}_{2}$ degradation by 15 -hydroxyprostaglandin dehydrogenase (15PGDH). ${ }^{80}$

$\mathrm{PGE}_{2}$ signals through four distinct GPCRs, termed EP receptors 1 through 4 (Figure 1). ${ }^{14}$ Each EP receptor has a distinct $\mathrm{G}$ protein coupling preference and downstream signal activation, and some of these signals counteract with one another. All four receptor subtypes are present in the lung and other organs associated with allergic responses. ${ }^{14}$ Signaling through the $\mathrm{EP}_{1}$ receptor increased cell $\mathrm{Ca}^{2+}$ and resulted in smooth muscle contraction. 
Activation of the $\mathrm{EP}_{2}$ and $\mathrm{EP}_{4}$ receptors increased intracellular cAMP concentrations, with resultant smooth muscle relaxation. ${ }^{81} \mathrm{EP}_{2}$ is expressed most abundantly in the uterus, lung and spleen. ${ }^{82}$ Stimulation of the $\mathrm{EP}_{2}$ receptor inhibited mast cell mediator release. $\mathrm{EP}_{4}$ receptor expression is greatest in the kidney and peripheral blood leukocytes; however, high level $\mathrm{EP}_{4}$ expression occurs in the thymus, lung and a number of other tissues. ${ }^{83} \mathrm{EP}_{3}$ receptors caused smooth muscle contraction by decreasing the rate of cAMP synthesis. ${ }^{84}$ $\mathrm{EP}_{3}$ receptors are unique because of the diversity created by multiple splice variants that produce alternate sequences in the C-terminal tail of this receptor subtype; however, the functional importance of these alternative splice variants is not well understood. ${ }^{82}$ Usually these splice variants of $\mathrm{EP}_{3}$ decrease cAMP generation, in contrast to signaling through $\mathrm{EP}_{2}$ and $\mathrm{EP}_{4}$ which increase cAMP. ${ }^{82}$ Therefore, $\mathrm{PGE}_{2}$ signaling may have opposing affects in different tissues dependent upon the relative contributions of the receptors that are stimulated in a given context.

Human studies of $\mathrm{PGE}_{\mathbf{2}}$ in allergic inflammation- $-\mathrm{PGE}_{2}$ is one of the most abundant COX products produced by the airway epithelium and smooth muscle. ${ }^{85 ; 86}$ Several studies suggest that endogenous $\mathrm{PGE}_{2}$ may be bronchoprotective in human asthma. ${ }^{87} \mathrm{PGE}_{2}$ produced by epithelial cells reduced vagal cholinergic contraction of airway smooth muscle. ${ }^{88}$ Bronchial epithelial cell-derived $\mathrm{PGE}_{2}$ also suppressed DC migration and pro-inflammatory cytokine protein expression. ${ }^{89}$ In this experiment, $\mathrm{PGE}_{2}$ inhibited dendritic cell by migration by signaling through the $\mathrm{EP}_{4}$ receptor, as DCs treated with an $\mathrm{EP}_{4}$ antagonist as well as DCs from $\mathrm{EP}_{4} \mathrm{KO}$ mice had reduced inhibition by airway epithelial cells with respect to secretion of proinflammatory cytokines. There was an inverse correlation between the sputum levels of $\mathrm{PGE}_{2}$ from asthmatics and sputum eosinophil counts. This result suggests that higher levels of $\mathrm{PGE}_{2}$ may protect against airway eosinophila. ${ }^{90 ; 91} \mathrm{PGE}_{2}$ inhalation also decreased the pulmonary early and late phase responses to inhaled allergen. ${ }^{92 ; 93}$ Inhaled $\mathrm{PGE}_{2}$ reduced the change in methacholine airway reactivity and blunted the number of airway eosinophils after inhaled allergen challenge. ${ }^{92}$ In addition, $\mathrm{PGE}_{2}$ inhibited both exercise-induced and aspirin-induced bronchoconstriction in patients sensitive to these challenges. ${ }^{94} ; 95$ Interestingly, although $\mathrm{PGE}_{2}$ significantly protected against decrements in pulmonary function in challenge models, it did not alter baseline $\mathrm{FEV}_{1}$ or methacholine reactivity. ${ }^{93}$ The results from these studies suggest that $\mathrm{PGE}_{2}$ has significant immunomodulatory properties than directly regulating airway caliber. This is supported by the observation that $\mathrm{PGE}_{2}$ inhalation prior to segmental allergen challenge significantly decreased BAL levels of $\mathrm{PGD}_{2}$, an important product of mast cell activation, and BAL concentrations of cys-LTs. ${ }^{96}$ Signaling through the $\mathrm{EP}_{4}$ receptor in human, guinea pig, and rat airways results in smooth muscle relaxation, ${ }^{97}$ whereas $\mathrm{EP}_{3}$ receptor signaling mediates the cough properties of $\mathrm{PGE}_{2} \cdot{ }^{98} \mathrm{PGE}_{2}$ in combination with the $\beta_{2}$-adrenergic receptor agonist albuterol also reduced human airway smooth muscle migration and mitogenesis, ${ }^{99 ; 100}$ revealing that $\mathrm{PGE}_{2}$ has a plethora of effects on airway function.

$\mathrm{PGE}_{2}$ is rapidly metabolized, leading investigators to use the more stable orally active $\mathrm{PGE}_{1}$ analogue, misoprostol, in studies of allergen-induced airway inflammation and lung function in humans. The effects of misoprostol in these studies have largely been negative. 
Misoprostol did not change pulmonary function, $\beta_{2}$ agonist use, or asthma severity score in aspirin-sensitive asthmatics. ${ }^{101}$ In mild asthmatics, misoprostol did not later either baseline lung function or histamine reactivity; however, it did lead to significant gastrointestinal side effects in one-third of study participants. ${ }^{102}$ It is important to note that misoprostol is significantly less potent than $\mathrm{PGE}_{2}$ in stimulating adenylate cyclase. ${ }^{103}$

Despite its capacity to reduce eosinophilia and allergic early- and late-phase responses, in vitro studies demonstrate that $\mathrm{PGE}_{2}$ has the ability to either stimulate or suppress immune cell function. PGE $_{2}$ reduced $T$ cell secretion of the Th1 cytokines IL- 2 and interferon- $\gamma$ in vitro, resulting in enhanced $\mathrm{T}$ cell differentiation toward a Th2 cytokine profile. ${ }^{104-107}$ These in vitro results suggesting $\mathrm{PGE}_{2}$ promoted Type 2 cytokine production may be regulated at the antigen presentation. Myeloid DCs matured in the presence of IFN- $\gamma$ produced Th1 CD4 ${ }^{+} \mathrm{T}$ lymphocyte responses, while DCs matured in $\mathrm{PGE}_{2}$ elicited Th2 responses. ${ }^{108} \mathrm{PGE}_{2}$ induction of $\mathrm{Th} 2$ cytokine secretion, mostly through its activity at the time of antigen presentation, does not necessarily contradict in vivo human studies that have suggested $\mathrm{PGE}_{2}$ is anti-inflammatory. More recently, in combination with IL-23, $\mathrm{PGE}_{2}$ induced differentiation and expansion of $\mathrm{CD}^{+}{ }^{+} \mathrm{Th} 17$, along with secretion of Th17 signature cytokines. ${ }^{109}$ Acute antigen challenge models probably more precisely reflect effector cell function, since allergic sensitization occurs much earlier in life.

In addition to $\mathrm{PGE}_{2}$ 's activity in the development of $\mathrm{CD} 4{ }^{+} \mathrm{Th} 1$ and $\mathrm{Th} 2$ cells, this prostanoid has important immunomodulatory effects on other inflammatory cells thought to be pathogenic in asthma. In a cell culture system, both $\mathrm{PGE}_{2}$ and cAMP reduced spontaneous eosinophil apoptosis, as did an $\mathrm{EP}_{2}$ agonist. ${ }^{110}$ Therefore, by prolonging eosinophil survival, $\mathrm{PGE}_{2}$ might increase the inflammatory potential of these cells in asthma. However, $\mathrm{PGE}_{2}$ was also reported to inhibit eosinophil chemotaxis, aggregation, degranulation, and IL-5-mediated survival. ${ }^{11 ; 112} \mathrm{PGE}_{2}$ inhibition of eosinophil trafficking was modulated through $\mathrm{EP}_{2}$ signaling. ${ }^{113}$ Therefore, the relevance of these in vitro findings to in vivo disease states is not clear.

$\mathrm{PGE}_{2}$ also regulated the secretion of granulocyte macrophage-colony stimulating factor (GM-CSF) from human airway smooth muscle cells ${ }^{114}$. The COX inhibitor indomethacin upregulated GM-CSF production by cultured human airway smooth muscle cells; however, exogenous $\mathrm{PGE}_{2}$ decreased this indomethacin-induced GM-CSF production, implying that $\mathrm{PGE}_{2}$ inhibited GM-CSF expression and the inflammation that is associated with this cytokine. ${ }^{114}$ In contrast, $\mathrm{PGE}_{2}$ augmented IL-6 and GM-CSF production resulting from IgEmediated mast cell degranulation via signaling through $\mathrm{EP}_{1}$ and $\mathrm{EP}_{3}$ receptors. ${ }^{115}$ There are conflicting reports as to the effect of $\mathrm{PGE}_{2}$ on mast cell production of differing mediators. $\mathrm{PGE}_{2}$ has been reported to either reduce ${ }^{116-118}$ or enhance ${ }^{119 ; 120}$ the release of histamine and other inflammatory mediators. It is possible that these differences may relate to the relative dominance of $\mathrm{EP}_{3}$ (activating) versus $\mathrm{EP}_{2}$ (inhibitory) signaling in a given mast cell population. For instance $\mathrm{PGE}_{2}$ can activate human mast cells through $\mathrm{EP}_{3}$, yet inhibit activation through the $\mathrm{EP}_{2}$-PKA signaling pathway. ${ }^{121}$

$\mathrm{PGE}_{2}$ is also thought to play a key role in aspirin-exacerbated respiratory disease (AERD) with inhibition of COX-1, but not COX-2, being closely aligned with the ability of NSAIDs 
such as aspirin to precipitate this form of bronchoconstriction. ${ }^{122} \mathrm{COX}-1$ inhibition blocks the production of endogenous $\mathrm{PGE}_{2}$, which restrains 5-LO-mediated cysteinyl leukotriene production which is, at least in part, responsible for the bronchoconstriction that occurs with NSAID ingestion. This concept is supported by studies which showed that inhaled $\mathrm{PGE}_{2}$ blunted both the increased urinary leukotriene $\mathrm{E}_{4}$ and bronchoconstriction that are characteristic of aspirin challenge in subjects with AERD. ${ }^{95 ; 123}$ Ingestion of COX-2 inhibitors did not result in symptoms in subjects with AERD, suggesting that COX-1 mediated $\mathrm{PGE}_{2}$ production is protective in this process. ${ }^{124}$

One of the leading proposed mechanisms of AERD pathophysiology is that subjects with this condition have differential metabolism of arachidonic acid, resulting in decreased $\mathrm{PGE}_{2}$ production. For instance, unstimulated epithelial cells from polyp tissues from subjects with AERD produced significantly decreased $\mathrm{PGE}_{2}$ compared to nasal epithelial cells from healthy subjects. ${ }^{125}$ Related to this decrease in $\mathrm{PGE}_{2}$, incubation of these epithelial cells from subjects with AERD resulted in significantly increased 15-hydroyeicostetraenoic acid, a product of 5-LO. ${ }^{125}$ Similarly, nasal tissue from subjects with nasal polyposis and AERD had decreased COX-2 mRNA expression and $\mathrm{PGE}_{2}$ concentrations, yet increased $\mathrm{LTC}_{4}$ synthase (the enzyme that converts $\mathrm{LTA}_{4}$ to $\mathrm{LTC}_{4}$ ), 5-LO mRNA, and cysteinyl leukotriene levels, compared to healthy subjects or those with only chronic rhinosinusitis. ${ }^{126}$ This alteration in $\mathrm{PGE}_{2}$ production in AERD patients is not limited to nasal tissue, as airway fibroblasts from subjects with AERD had decreased $\mathrm{PGE}_{2}$ production compared to health subjects. In this investigation, there was a decreased in COX-1, but not COX-2, protein expression in the AERD subjects' airway fibroblasts compared to those from healthy subjects. ${ }^{127}$ Fibroblasts from nasal tissue from subjects with AERD produced significantly less PGE $_{2}$ following IL-1 $\beta$ stimulation compared to normal subjects or those with nasal polyps who were aspirin tolerant. ${ }^{128}$

There is not only a decrease in $\mathrm{PGE}_{2}$ production in tissue from subjects with AERD compared to healthy subjects, but also aberrant expression of $\mathrm{PGE}_{2}$ receptors in tissues from AERD subjects. There was a decreased density of $\mathrm{EP}_{2}$ expression, and an increased expression of cysteinyl leukotriene receptors, in nasal polyp tissue from AERD subjects compared to aspirin tolerant subjects. ${ }^{129}$ There was reduced $\mathrm{EP}_{2}$ expression on airway $\mathrm{T}$ cells, macrophages, mast cells, and neutrophils from AERD subjects compared to subject with aspirin tolerant asthma. ${ }^{130}$ There was also a significantly decreased percentage of neutrophils, mast cells, eosinophils, and $\mathrm{T}$ cells expressing $\mathrm{EP}_{2}$, but not $\mathrm{EP}_{1}, \mathrm{EP}_{3}$, or $\mathrm{EP}_{4}$ in nasal biopsies from subjects with AERD compared to aspirin tolerant controls. ${ }^{131}$

Investigations into possible genetic regulation of AERD using a candidate gene approach revealed that polymorphisms in the $\mathrm{EP}_{2}$ gene confer susceptibility to AERD. Evaluation of allelic association of 370 single nucleotide polymorphisms (SNPs) of genes that regulate the arachidonic acid metabolic cascade revealed multiple SNPs in the $\mathrm{EP}_{2}$ gene that were significantly associated with AERD. ${ }^{132}$ SNPs in the $\mathrm{EP}_{2}$ promoter gene, uS5, uS5b, and uS7 were significantly associated with AERD and analysis of haplotypes constructed to linkage disequilibrium patterns showed a significant association with AERD. The most significantly associated SNP, uS5, located in the regulatory region of the $\mathrm{EP}_{2}$ gene, was in a STATsbinding consensus sequence (AERD 31.1\% versus control 22.1\% [permutation $\mathrm{P}=0.0016$ ] or 
versus aspirin-tolerant asthma $22.2 \%$ [permutation $\mathrm{P}=0.0017$ ]). In an in vitro reporter assay, the site containing the uS5 allele showed reduced transcription activity. These results suggest that uS5 allele serves as a target of a transcription repressor protein. ${ }^{132} \mathrm{~A}$ functional SNP of the $\mathrm{EP}_{2}$ gene associated with risk of AIA should decrease the transcription level, resulting in reduction of the $\mathrm{PGE}_{2}$ retraining mechanism of inflammation and involvement in the molecular mechanism underlying AERD. In another study, genetic polymorphisms in $\mathrm{EP}_{2}, \mathrm{EP}_{3}, \mathrm{EP}_{4}$, the $\mathrm{PGI}_{2}$ receptor (IP), and the thromboxane A receptor (TP) were associated with AERD. ${ }^{133}$ Therefore, there is abundant data suggesting that decreased $\mathrm{PGE}_{2}$ production and reduced expression of $\mathrm{EP}_{2}$ on a variety of cell types is pathogenic in AERD.

Mouse studies of $\mathrm{PGE}_{\mathbf{2}}$ in allergic inflammation-In the OVA-sensitization and challenge model, $\mathrm{EP}_{3} \mathrm{KO}$ mice had increased allergic inflammation compared to WT mice, while there were no differences in the pulmonary allergic inflammation between $\mathrm{WT}, \mathrm{EP}_{1}$ $\mathrm{KO}, \mathrm{EP}_{2} \mathrm{KO}$, and $\mathrm{EP}_{4} \mathrm{KO}$ mice. ${ }^{134}$ Compared to WT mice, $\mathrm{EP}_{3} \mathrm{KO}$ mice had increased airway eosinophils, neutrophils, and lymphocytes, as well as increased IL-4, IL-5, and IL-13 in BAL fluid. ${ }^{134}$ Administration of the $\mathrm{EP}_{3}$ agonist $\mathrm{AE}-248$ to OVA-sensitized and challenged WT mice significantly inhibited allergic airway cellularity and tended to inhibit airway mucus and airway responsiveness to methacholine. ${ }^{134}$ In ex vivo experiments, lungs from OVA-sensitized and challenged $\mathrm{EP}_{3}$-deficient or WT mice were harvested and then challenged with OVA. ${ }^{134}$ In these experiments, there was significantly decreased histamine and cys-LT in lungs from WT mice treated with an $\mathrm{EP}_{3}$ agonist, suggesting that $\mathrm{PGE}_{2}$ may signal through EP on mast cells in vivo to reduce mediator release. ${ }^{134}$ The results of these studies would not have been predicted from in vivo analyses, since $\mathrm{EP}_{3}$ receptor signaling causes mast cell activation in vitro, whereas $\mathrm{EP}_{2}$ receptor signaling is inhibitory. ${ }^{121}$ Other studies support the notion that $\mathrm{PGE}_{2}$ restrains allergic airway inflammation in mice. Subcutaneous $\mathrm{PGE}_{2}$ inhibited lung eosinophilia and Th2 cytokine protein expression in a house dust mite model of allergic inflammation. ${ }^{135}$ The effect of $\mathrm{PGE}_{2}$ on mouse mast cell function in vitro seems to contrast that of other cells involved in the allergic inflammatory response. For example, $\mathrm{PGE}_{2}$ stimulated mast cell chemotaxis and cytokine production through mTORC2 activation. ${ }^{136}$ The chemotactic activity of $\mathrm{PGE}_{2}$ on mouse mast cells occurs via $\mathrm{EP}_{3}$ activation. ${ }^{137}$

$\mathrm{PGE}_{2}$ expression is reduced in chronic allergen exposure, likely a result of allergic inflammation, and the consequence of this reduction in $\mathrm{PGE}_{2}$ is increased airway remodeling. In this model, there was an inverse relationship between the number of allergen challenges and both COX-2 and mPGES-1 expression in lung fibroblasts, resulting in decreased cytokine-induced $\mathrm{PGE}_{2}$ production. ${ }^{138}$ mPGES-1 produced $\mathrm{PGE}_{2}$ did not have an effect on allergen sensitization or effector $\mathrm{T}$ cell responses in a house dust mite model comparing the phenotype of mPGES-1 KO and WT mice. ${ }^{139}$ However, mPGES-1 KO mice had significantly increased vascular smooth muscle cells and thickness of intrapulmonary vessels following allergen challenge. ${ }^{139}$ These findings suggest that $\mathrm{PGE}_{2}$ produced by mPGES-1 protected the pulmonary vasculature from remodeling during allergen-induced lung inflammation. $\mathrm{PGE}_{2}$ also regulates airway tone in mice. Immunolologically naïve mice that lack 15-PGDH, the major catabolic enzyme of $\mathrm{PGE}_{2}$, and resulting elevated levels of $\mathrm{PGE}_{2}$, had reduced bronchoconstrictor response to methacholine. ${ }^{140}$ Similarly, mice that had 
increased $\mathrm{PGE}_{2}$ levels as a result of over-expression of $\mathrm{PGE}_{2}$ synthase in the lung had reduced methacholine-induced airway constriction. ${ }^{140}$ Thus $\mathrm{PGE}_{2}$ protected against lower airway bronchoconstriction, and other reports suggest that this effect is mediated through $\mathrm{EP}_{2}$. Pretreatment with aerosolized $\mathrm{PGE}_{2}$ inhibited methacholine-induced bronchoconstriction in WT, but not $\mathrm{EP}_{2} \mathrm{KO}$ mice. ${ }^{141} \mathrm{In}$ addition, methacholine-induced bronchoconstriction was reversed by aerosolized $\mathrm{PGE}_{2}$ in WT, but not $\mathrm{EP}_{2} \mathrm{KO}$ mice. ${ }^{141}$ This concept was solidifed by another group that reported that $\mathrm{PGE}_{2}$-induced bronchodilation was a consequence of direct activation of $\mathrm{EP}_{2}$ receptors on airway smooth muscle, while $\mathrm{PGE}_{2}$ signaling through $\mathrm{EP}_{1}$ and $\mathrm{EP}_{3}$ led to bronchoconstriction. ${ }^{142}$ Taken together, these studies suggest that $\mathrm{PGE}_{2}$ regulates homeostasis of bronchomotor tone and pulmonary immune responses through different respective receptors. Based on the available animal data cited above, agents that stimulate EP2, or that antagonize EP1 and EP3, may be useful therapeutic targets for the treatment of asthma.

In vivo mouse experiments support the concept that $\mathrm{PGE}_{2}$ is critical in protection against aspirin-exacerbated respiratory disease. mPGES-1 KO mice with dust mite-induced allergic airway inflammation developed increased airways resistance, enhanced mast cell activation, and increased cysteinyl leukotriene production following lysine aspirin challenge. ${ }^{143} \mathrm{~A}$ stable $\mathrm{PGE}_{2}$ analog, 16, 16-dimethyl $\mathrm{PGE}_{2}$, significantly reduced lysine aspirin-induced airways resistance, mast cell-induced histamine release, and cysteinyl leukotriene generation. $\mathrm{EP}_{2}$ and $\mathrm{EP}_{4}$ receptor agonists had similar protective effects as 16, 16-dimethyl $\mathrm{PGE}_{2}$ on histamine and cysteinyl leukotriene levels, while the $\mathrm{EP}_{2}$ agonist reduced airways resistance to a greater degree than did the EP4 agonist. In this model, the lysine aspirininduced airways resistance and histamine release was dependent on cysteinyl leukotrienes, providing evidence that $\mathrm{PGE}_{2}$ negatively regulates lysine aspirin-induced leukotrienemediated airway constriction and inflammation. Further studies revealed that lysine aspirininduced cysteinyl leukotriene and mast cell activation were dependent upon platelets adhering to granulocytes and signaling through the thromboxane receptor TP. ${ }^{143}$ Therefore, COX-1 mediated inhibition of $\mathrm{PGE}_{2}$ synthesis increases mast cell activation and platelet mediated TP-dependent cysteinyl leukotriene production.

\section{Prostaglandin $\mathrm{F}_{2 a}$}

$\mathrm{PGF}_{2 \mathrm{a}}$ is produced by PGF synthase (PGFS). ${ }^{144}$ PGFS has two main activities. First, PGFS catalyzes the formation of $\mathrm{PGF}_{2 a}$ from $\mathrm{PGH}_{2}$ by $\mathrm{PGH}_{2}$ 9,11-endoperoxide reductase in the presence of NADPH. Second, PGFS catalyzes the conversion of $\mathrm{PGF}_{2 \mathrm{a}}$ from $\mathrm{PGD}_{2}$ by $\mathrm{PGD}_{2}$ 11-ketoreductase. ${ }^{144}$ The PGFS binding sites for $\mathrm{PGH}_{2}$ and $\mathrm{PGD}_{2}$ are proposed to be distinct. ${ }^{144}$ PGFS is expressed in lung and peripheral blood lymphocytes, suggesting a possible role in allergic diseases such as asthma. ${ }^{145}$ PGFS is inhibited by non-steroidal antiinflammatory drugs (NSAIDS) such as indomethacin and this may partially explain the protective effect of this class of drugs in some gastrointestinal tumors in which PGFS activity is high. ${ }^{144} \mathrm{PGF}_{2 a}$ binds a solitary receptor, termed FP (Figure 1) which is the most promiscuous of the prostanoid GPCRs in binding the principal prostaglandins. Both $\mathrm{PGD}_{2}$ and $\mathrm{PGE}_{2}$ both to $\mathrm{FP}$ at nanomolar concentrations. ${ }^{146}$ Selective FP agonists such as fluprostenol and latanoprost have been produced that are used in clinical settings as a result of these agents' ocular hypotensive properties. ${ }^{146} \mathrm{PGF}_{2 \alpha}$ has critical functions in 
reproduction, renal physiology, and modulation of intraocular pressure. Tissue distribution of FP receptor mRNA expression is greatest in the ovarian corpus luteum, followed by the kidney, with lower-level expression in the lung, stomach, and heart. ${ }^{147}$ FP expression has not been detected in the spleen, thymus, or on immune cells. Therefore, in contrast to the other prostaglandins, $\mathrm{PGF}_{2 a}$-FP receptor signaling does not seem to have an important role in inflammatory and immunological processes. ${ }^{146}$

Human studies of $\mathbf{P G F}_{2 a}-\mathrm{PGF}_{2 a}$ has not been studied to nearly the same degree as $\mathrm{PGD}_{2}$ or $\mathrm{PGE}_{2}$ in allergic disease and asthma. $\mathrm{PGF}_{2 \mathrm{a}}$ inhalation led to a dose-related decrease in specific airway conductance in both control and asthmatic subjects. ${ }^{148-150}$ While there has been a relatively small inter-individual variation in healthy control subjects in response to inhaled $\mathrm{PGF}_{2 \mathrm{a}}$, there has been a wide variation in the pulmonary function response to $\mathrm{PGF}_{2 \mathrm{a}}$ in asthmatics. ${ }^{150}$ Asthmatics who inhaled $\mathrm{PGF}_{2 \mathrm{a}}$ experienced wheezing, coughing and chest irritation within 3 to 4 minutes, while watery sputum also occurred shortly thereafter. ${ }^{150}$ Maximal decrease in specific airway conductance after $\mathrm{PGF}_{2 a}$ occurred 6 minutes after inhalation and recovery took place within 30 minutes. ${ }^{150}$ Asthmatic subjects experienced an approximate 150 -fold greater sensitivity to $\mathrm{PGF}_{2 \mathrm{a}}$ than did healthy controls, yet asthmatics were only 8.5 -fold more sensitive to histamine than nonasthmatic subjects. ${ }^{150}$ There was decreased variation in individual responses to histamine compared to inhaled $\mathrm{PGF}_{2 a}$ challenge; however, there was a correlation of sensitivity to both mediators with each other. ${ }^{150}$ In general, women had a reduced bronchoconstrictor response to $\mathrm{PGF}_{2 \mathrm{a}}$ compared to men. ${ }^{150}$ Both $\mathrm{PGE}_{2}$ and isoprenaline shortened recovery from the reduction in pulmonary function caused by inhalation of $\mathrm{PGF}_{2 a}$; however, neither atropine, disodium cromoglycate, nor flufenamic acid prevented $\mathrm{PGF}_{2 \mathrm{a}}$-induced bronchoconstriction. ${ }^{150}$ $\mathrm{PGF}_{2 \mathrm{a}}$, and $\mathrm{PGE}_{2}$ as well, decreased exhaled nitric oxide (NO) concentrations in both healthy controls and asthmatic subjects; however, the meaning of this outcome is unknown. ${ }^{151}$ Although FP is not expressed on immune cells, there is some evidence that $\mathrm{PGF}_{2 a}$ may have a role on airway inflammation. In subjects with asthma, the magnitude of sputum eosinophilia correlated with the log sputum $\mathrm{PGF}_{2 a}$ concentrations, while there was an inverse correlation between sputum eosinophilia and $\mathrm{PGE}_{2}$ levels, and no correlation between the number of sputum eosinophils and sputum levels of cys-LTs, thromboxane, and $\mathrm{PGD}_{2} \cdot{ }^{91}$

Mouse studies of $\mathrm{PGF}_{2 a}$ in allergic inflammation-To our knowledge, there are no published studies examining the effect of $\mathrm{PGF}_{2 a}$ administration or signaling through the FP receptor in the mouse allergen challenge model. An FP-deficient mouse has been created and these mice had attenuated bleomycin-induced pulmonary fibrosis independent of TGF- $\beta$ expression. ${ }^{152}$ To date, no studies have examined whether FP-deficient mice are protected from collagen deposition and airway wall remodeling in a chronic allergen challenge model.

\section{Prostaglandin $\mathrm{I}_{2}$}

$\mathrm{PGI}_{2}$ is converted from $\mathrm{PGH}_{2}$ by PGI synthase (PGIS) and the gene encoding PGIS is located on chromosome 20q13.11-13. ${ }^{153}$ PGIS is strongly expressed in the heart, lung, smooth muscle, kidney, and ovary and expressed at moderate levels in the brain, pancreas, and prostate. ${ }^{153}$ There is low level PGIS expression in the placenta, spleen, and 
leukocytes. ${ }^{153} \mathrm{PGI}_{2}$ signals through its receptor, IP, a GPCR (Figure 1). ${ }^{82}$ Binding of $\mathrm{PGI}_{2}$ to its receptor activates adenylate cyclase via $\mathrm{G}_{\mathrm{s}}$ in a dose-dependent manner, increasing cAMP production. ${ }^{154}$ This increase in intracellular cAMP mediates the ability of $\mathrm{PGI}_{2}$ to inhibit platelet aggregation, thus dispersing existing platelet aggregates both in vitro and in human circulation. ${ }^{154}$ Northern blot analysis reveals that IP mRNA is expressed to the highest degree in the thymus, while high levels of IP mRNA expression are also found in spleen, heart, lung, and neurons in the dorsal root ganglia. IP is also expressed on mouse bone marrow-derived dendritic cells (BMDCs). ${ }^{155}$ The $\mathrm{PGI}_{2}$ analogs iloprost and cicaprost inhibited BMDC production of proinflammatory cytokines (IL-12, TNF-alpha, IL-1alpha, IL-6) and chemokines (MIP-1alpha, MCP-1), yet these analogs increased the production of the immunoinhibitory cytokine IL-10 by BMDCs. ${ }^{155}$ The modulatory effect was associated with IP-dependent increase in intracellular cAMP and reduction of NF- $\kappa \mathrm{B}$ activity. ${ }^{155}$ Iloprost and cicaprost also inhibited LPS-induced expression of CD86, CD40, and MHC class II molecules by BMDCs and reduced the ability of BMDCs to stimulate antigenspecific $\mathrm{CD}^{+}{ }^{+} \mathrm{T}$ cell proliferation and production of IL-5 and IL-13. ${ }^{155}$ Iloprost also enhanced human DC production of IL-10 and in co-culture experiments of iloprost-treated DCs and naïve T cells, there was induction of T regulatory cells. ${ }^{156} \mathrm{IP}$ is also expressed in T cells of mice, along with the $\mathrm{PGE}_{2}$ receptor (EP) subtypes and the thromboxane receptor (TP). ${ }^{157}$ In addition IP is expressed by kidney smooth muscle and epithelial cells. ${ }^{158}$ Messenger RNA for IP is expressed in both $\mathrm{CD} 4^{+} \mathrm{Th} 1$ and Th2 cells. ${ }^{159}$ Thus, IP has been located on several different cell types, including those critical to the adaptive immune response.

Human studies of $\mathrm{PGI}_{2}$ in allergic inflammation $-\mathrm{PGI}_{2}$ and $\mathrm{PGD}_{2}$ were the major COX products produced in antigen-induced anaphylactic reactions of human lung parenchyma, on the order of 3- to 7-fold increased concentrations than that of the other prostanoids. ${ }^{160}$ The $\mathrm{PGI}_{2}$ metabolite 6-keto-PGF ${ }_{1 \mathrm{a}}$ was present in concentrations 2-to-3-fold greater than all the other prostanoids in both airway and subpleural lung fragments in an in vitro anaphylaxis assay of passively sensitized human lung. ${ }^{161}$ Surprisingly, plasma 6-keto$\mathrm{PGF}_{1 \mathrm{a}}$ was increased subsequent to antigen challenge in which asthmatic subjects were pretreated with indomethacin. ${ }^{162}$ Thus, $\mathrm{PGI}_{2}$ is produced in abundance in allergic inflammatory responses in the lung, presumably a reflection of activated endothelial cells that express almost all the PGIS in the human airway.

Most of the published intervention studies examining the modulatory effect of $\mathrm{PGI}_{2}$ in human asthma were performed over 20 years ago and an important limitation of these older reports is that $\mathrm{PGI}_{2}$ (half-life 3-5 minutes) was used, rather than recently developed stable analogs. Therefore, these older studies may not accurately reflect the therapeutic capability of the currently available class of $\mathrm{PGI}_{2}$ agents. Pretreatment with $\mathrm{PGI}_{2}$ had no effect on allergen-induced immediate phase bronchoconstriction. ${ }^{163}$ In another study, $\mathrm{PGI}_{2}$ protected against both exercise and ultrasonic water-induced bronchospasm; however, it again had no effect on allergen-induced airway reactivity. ${ }^{164}$ Inhaled $\mathrm{PGI}_{2}$ also had no effect on specific airway conductance, but did result in consistent bronchodilation in two asthmatic subjects. In this study, there was a significant effect of $\mathrm{PGI}_{2}$ on the cardiovascular system. Inhaled $\mathrm{PGI}_{2}$ resulted in a fall in both diastolic $(20 \pm 3 \mathrm{mmHg})$ and systolic $(8 \pm 2 \mathrm{mmHg})$ blood 
pressure, as well as an increased pulse rate $\left(29 \pm 3\right.$ beats per minute) ${ }^{165}$ Intravenous $\mathrm{PGI}_{2}$ administration had no effect on the fall in airflow induced by aspirin in subjects with aspirininduced asthma. ${ }^{166}$ Somewhat contradictory results of the effect of inhaled $\mathrm{PGI}_{2}$ in subjects with mild asthma have been reported. ${ }^{167}$ In these studies PGI $_{2}$ did not alter specific airway conductance, but resulted in a concentration-dependent decrease in $\mathrm{FEV}_{1}$. In contrast, these same investigators reported that $\mathrm{PGI}_{2}$ protected against bronchoconstriction induced by either $\mathrm{PGD}_{2}$ or methacholine. The authors proposed that these disparate findings might be explained by $\mathrm{PGI}_{2}$ 's marked vasodilator effect, resulting in airway narrowing through mucosal blood engorgement, while this same phenomenon possibly reduced the spasmogenic properties of other inhaled mediators by increasing their clearance from the airways. An oral $\mathrm{PGI}_{2}$ analog (OP-41483) did not change $\mathrm{FEV}_{1}$ or airways responsiveness to methacholine in stable asthmatics. ${ }^{168}$ Since this last report which was published in 1991, to our knowledge, there has been only other published manuscript examining $\mathrm{PGI}_{2}$ in human allergic inflammation in the lung or asthma. In this report, the feasibility of administering inhaled iloprost to subjects with mild atopic asthma was examined. ${ }^{169}$ Subjects inhaled iloprost four times daily at either 2.5 or $5 \mu$ for 14 days. In this safety study, chronic iloprost inhalation had did not have a negative effect on spirometry or methacholine responsiveness. ${ }^{169}$ The therapeutic potential of newer, more stable $\mathrm{PGI}_{2}$ analogs in asthma, already approved for use in pulmonary hypertension, remains unexplored.

Mouse studies of $\mathbf{P G l}_{2}$ in allergic inflammation-Four studies using mouse models suggest that endogenous $\mathrm{PGI}_{2}$ signaling through IP restrains allergic airway inflammation. In a model of short-term OVA challenge, IP KO mice had greater lung production of IL-4 and IL-5, serum antigen-specific and total IgE levels, and airway cellularlity compared to WT mice. ${ }^{170}$ In another study, the period of allergen challenge was extended to mimic chronic allergen exposure. In this report, IP KO mice had increased airway eosinophils and lymphocytes, Th2 cytokine levels, and hydroxyproline concentrations compared to WT mice. ${ }^{171}$ IP KO mice had increased inflammatory and physiologic changes compared to WT mice in the model of bleomycin-induced fibrosis. ${ }^{172}$ In another bleomycin model of lung injury, mice that overexpressed PGIS in airway epithelial cells were protected against lung injury and had decreased production of $\mathrm{F}_{2}$-isoprostanes, a marker of oxidant injury. In these experiments, $\mathrm{PGI}_{2}$ stimulated the expression of $\mathrm{NAD}(\mathrm{P}) \mathrm{H}$ :quinone oxidoreductase type I (NQO1), an enzyme that prevents generation of reactive oxidant species. ${ }^{173}$

Supporting the concept that $\mathrm{PGI}_{2}$ restrains airway inflammation, inhaled iloprost reduced maturation and migration of lung DCs to the mediastinal lymph nodes following intranasal antigen administration, resulting in decreased induction of an allergen-specific Th2 response in these nodes. ${ }^{174}$ In this in vivo model, iloprost-treated DCs also inhibited Th2 differentiation from naive $\mathrm{T}$ cells and did not boost effector cytokine production in primed Th2 cells. ${ }^{174}$ Not only did $\mathrm{PGI}_{2}$ downregulate mature DC function, but it also inhibited immature DC function. The $\mathrm{PGI}_{2}$ analog cicaprost decreased uptake of FITC-labeled OVA by immature BMDCs. ${ }^{175}$ In addition, cicaprost increased immature BMDC dissolution of podosomes, focal adhesion structures that are necessary for DC adherence to extracellular matrix in the lung and other tissues. ${ }^{175}$ When podosomes are dissolved, the DC is no longer tethered to the epithelium and can migrate to the regional lymph node. Podosome 
dissolution usually only takes place after the $\mathrm{DC}$ has taken up antigen; however, $\mathrm{PGI}_{2}$ regulated podosome dissolution allows for the DC to leave the environment-epithelial cell interface prior to antigen uptake. Cicaprost further increased pro-MMP-9 production, which has an essential role in DC egress from mucosal surfaces to draining lymph nodes. ${ }^{175}$ Further, cicaprost increased cell surface CCR7 expression with resultant chemotactic migration toward CCL19 and CCL21 produced in the T cell zone of the lymph node. These in vitro results suggested that cicaprost promoted migration of immature DCs from mucosal surface to draining lymph nodes and this concept was supported by the finding that migration of immature green fluorescent protein expressing BMDCs to draining lymph nodes was enhanced by pretreatment with cicaprost. Cicaprost-mediated inhibition of antigen uptake by immature DCs, enhanced podosome dissolution, heightened pro-MMP-9 production, and increased CCR7 expression were all dependent upon signaling through the IP receptor. ${ }^{175}$ These data reveal that $\mathrm{PGI}_{2}$ inhibits DC-mediated immune activation by enhancing immature DC migration and also by decreasing antigen uptake, providing two additional potential mechanisms by which $\mathrm{PGI}_{2}$ may be therapeutically beneficial in hypersensitivity diseases, such as asthma.

While these results in animal models of allergic inflammation are encouraging for the use of $\mathrm{PGI}_{2}$ in the treatment of allergic airway inflammation, cost and difficulty in drug delivery are currently obstacles. ${ }^{176 ; 177}$ However, the development of less expensive and longer acting agonists may make stable analogs of $\mathrm{PGI}_{2}$ a viable therapeutic option.

\section{Thromboxane $\mathbf{A}_{2}$}

Thromboxane $\mathrm{A}_{2}\left(\mathrm{TXA}_{2}\right)$ is the major product of arachidonic acid metabolism formed by platelets and is a potent platelet aggregating agent. ${ }^{178}$ Thromboxane synthase (TXAS) is an endoplasmic reticulum membrane protein that catalyzes the conversion of prostaglandin $\mathrm{H}_{2}$ to thromboxane $\mathrm{A}_{2} \cdot{ }^{179}$ TXAS is localized to band q33-q34 of the long arm of chromosome 7 in humans. ${ }^{179}$ TXAS is expressed abundantly in lung, liver, kidney, and blood cells, including megakaryocytes and monocytes. ${ }^{179}$ Lower, but still significant, levels of TXAS mRNA are observed in kidney, placenta and thymus. ${ }^{179} \mathrm{TXA}_{2}$ is principally produced by platelets, monocytes, macrophages, neutrophils and lung parenchyma. ${ }^{180}$ After it is formed, $\mathrm{TXA}_{2}$ is nonezymatically hydrolyzed to thromboxane $\mathrm{B}_{2}$, which is further metabolized to the principle urinary metabolites 2,3-dinor-thromboxane $\mathrm{B}_{2}$ and 11-dehydro-thromboxane $\mathrm{B}_{2 .}{ }^{181}$ The TXA 2 receptor is termed TP (Figure 1) and there are two isoforms, TPa and TP $\beta$, which are produced by alternative splicing occurring in the carboxy-terminal region after the seventh transmembrane domain. ${ }^{182}$ Both of these isoforms couple to a Gq protein resulting in phospholipase $\mathrm{C}$ activation, calcium release, and activation of protein kinase C. ${ }^{183}$ However, these receptor isoforms couple oppositely to adenylate cyclase, as TPa activates adenylate cyclase while TP $\beta$ inhibits this enzyme. ${ }^{184}$ The TP receptors are localized to both plasma membrane and cytosolic compartments and are mainly distributed in tissues rich in vasculature such as lung, heart and kidney. ${ }^{146}$ These GPCRs are involved in a myriad of physiological and pathological processes, including vasoconstriction that is implicated in vascular diseases such as hypertension, atherosclerosis, stroke, and myocardial infarction. ${ }^{185}$ 
Human studies of TXA in allergic inflammation- $\mathrm{TXA}_{2}$ has a half-life of approximately 30 seconds, ${ }^{186}$ and because of this lability there is a paucity of in vivo studies examining the effect of $\mathrm{TXA}_{2}$ in the human airway. $\mathrm{TXB}_{2}$ did not cause bronchoconstriction of human airway in vivo. ${ }^{187}$ However, $\mathrm{TXA}_{2}$ was a potent stimulant of in vitro smooth muscle constriction. ${ }^{178} \mathrm{TXA}_{2}$ might have a role in the physiology associated with acute asthma exacerbations. Levels of $\mathrm{TXA}_{2}$ metabolites were increased 4-6 fold in the urine of patients admitted to the hospital with asthma compared to non-smoking controls admitted for other diagnoses. ${ }^{187}$ Allergic asthmatics subjected to inhaled allergen challenge had a significant increase in urinary excretion of TXA 2 products; ${ }^{34 ; 188}$ however, others have not found similar results. ${ }^{187}$ Inhibition of platelet COX by low dose aspirin inhibited the increase in urinary 2,3-dimer thromboxane, supporting the concept that allergen inhalation causes platelet activation. Allergic asthmatics pre-treated with indomethacin prior to inhaled allergen challenge resulted in a significant decrease in urinary $\mathrm{TXA}_{2}$ metabolites; however, no change in pulmonary function occurred. ${ }^{34}$ Subjects that experience ozone-induced airway hyperresponsiveness had significant greater concentrations of $\mathrm{TXA}_{2}$ in BAL in addition to airway neutrophilia. ${ }^{189}$ Similarly, $\mathrm{LTB}_{4}$ inhalation also resulted in greater levels of $\mathrm{TXA}_{2}$ and neutrophils in BAL fluid. ${ }^{190}$

$\mathrm{TXA}_{2}$ antagonists have been used in challenge models and in short-term studies in asthma to discern the effect of $\mathrm{TXA}_{2}$ on pulmonary function and airway reactivity. In a nonrandomized, uncontrolled study the TP antagonist seratrodast (AA-2414) significantly reduced bronchial reactivity in asthmatic subjects after 4 weeks of once daily therapy compared to a pre-treatment baseline. ${ }^{191}$ Seratrodast had no effect on either exhaled nitric oxide or on the percentage of eosinophils in sputum. ${ }^{191}$ In a follow-up double blind, placebo-controlled study of asthmatic treated for four weeks, seratrodast treatment resulted in significant improvements in symptom score, peak expiratory flow (PEF) rates, diurnal variation of PEF, and bronchial responsiveness compared with placebo. ${ }^{192}$ These improvements were associated with a significant decrease in the number of submucosal eosinophils on bronchial biopsy. ${ }^{192}$ Seratrodast significantly decreased the number of cells in the epithelium expressing the chemokines RANTES (CCL5) and macrophage inflammatory protein (MIP)-1a (CCL3). Seratrodast also diminished the number of cells in the submucosa expressing monocyte chemotactic protein-3, RANTES, MIP-1a, and eotaxin (CCL11). ${ }^{192}$ These findings suggest that $\mathrm{TXA}_{2}$ antagonism inhibits allergic inflammation in the lung, although the mechanisms are not well defined.

Mouse studies of $\mathbf{T X A}_{\mathbf{2}}$ in allergic inflammation-Both the $\mathrm{TXA}_{2}$ synthase inhibitor OKY-046 and the TP receptor antagonist S-1452 significantly reduced BAL total cells and eosinophils in a dose response relationship in OVA-sensitized and challenged mice. ${ }^{193}$ Treatment with either the TXA 2 synthase inhibitor or the TP receptor antagonist significantly reduced antigen-specific activation of splenic mononuclear cells from sensitized mice in ex vivo experiments as defined by pro-inflammatory cytokine production. ${ }^{193}$ A recent study revealed that genetic deletion of TP receptors from mice lacking mPGES-1 prevented the development of dust mite-induced pulmonary eosinophilia, airway hyperresponsiveness, Th2 cytokine generation, and vascular remodeling. ${ }^{194}$ Thus, the pathogenic contributions from $\mathrm{TXA}_{2}$ may be amplified when local concentrations of 
$\mathrm{PGE}_{2}$ are low. The available mouse data suggests that inhibiting TP signaling, either through a receptor antagonist or through neutralizing $\mathrm{TXA}_{2}$, may be a therapeutic target in the treatment of asthma.

\section{FIVE-YEAR VIEW}

Future research will continue to expand understanding of PG signaling pathways and further identify therapeutic options in allergic lung disease and asthma. Specifically, research in the next five years will broaden our understanding of the molecular signaling pathways of PGs with further emphasis on modification of downstream gene expression. Further knowledge of these signaling pathways will provide additional therapeutic targets outside of traditional PG analogue therapy. The short half-life of PGs limits their potential use in vivo; however, discoveries in extending the bioactivity of PG analogs may increase their therapeutic applicability. One strategy for expanding the role of PG analogue therapy in asthma will be through the development of new delivery mechanisms in humans. Currently, several delivery options are being investigated in animal studies but have yet to be transitioned to human studies. PG receptor agonists and antagonists currently represent a promising option for therapy in asthma. However, further human studies will be needed to establish their role in the treatment of asthma. Together, these strategies represent the likely options for expanding the role of PGs in asthma therapy in the next five years.

\section{Acknowledgments}

This work was supported by NIH Grants R01 AI 111820, U19 AI 095227-02, R01 HL 090664-04, and Veteran Affairs Grant 2I01BX000624.

\section{Reference List}

1. Ricciotti E, Fitzgerald GA. Prostaglandins and inflammation. Arterioscler Thromb Vasc Biol. 2011; 31(5):986-1000. [PubMed: 21508345]

2. Goldblatt MW. A depressor substance in seminal fluid. J Soc Chem Ind (Lond). 1933; 52:10561057.

3. von Euler US. A depressor substance in the vesicular gland. J Physiol. 2014; 84:21P.

4. Piper PJ, Vane JR. Release of additional factors in anaphylaxis and its antagonism by antiinflammatory drugs. Nature. 1969; 223(5201):29-35. [PubMed: 4389381]

5. Dennis EA, Cao J, Hsu YH, et al. Phospholipase A2 enzymes: physical structure, biological function, disease implication, chemical inhibition, and therapeutic intervention. Chem Rev. 2011; 111(10):6130-6185. [PubMed: 21910409]

6. Balestrieri B, Hsu VW, Gilbert H, et al. Group V secretory phospholipase A2 translocates to the phagosome after zymosan stimulation of mouse peritoneal macrophages and regulates phagocytosis. J Biol Chem. 2006; 281(10):6691-6698. [PubMed: 16407308]

7. Giannattasio G, Fujioka D, Xing W, et al. Group V secretory phospholipase A2 reveals its role in house dust mite-induced allergic pulmonary inflammation by regulation of dendritic cell function. $\mathrm{J}$ Immunol. 2010; 185(7):4430-4438. [PubMed: 20817863]

8. Henderson WR Jr, Oslund RC, Bollinger JG, et al. Blockade of human group X secreted phospholipase A2 (GX-sPLA2)-induced airway inflammation and hyperresponsiveness in a mouse asthma model by a selective GX-sPLA2 inhibitor. J Biol Chem. 2011; 286(32):28049-28055. [PubMed: 21652694]

9. Hallstrand TS, Chi EY, Singer AG, et al. Secreted phospholipase A2 group X overexpression in asthma and bronchial hyperresponsiveness. Am J Respir Crit Care Med. 2007; 176(11):1072-1078. [PubMed: 17901411] 
10. Hallstrand TS, Lai Y, Ni Z, et al. Relationship between levels of secreted phospholipase A(2) groups IIA and $X$ in the airways and asthma severity. Clin Exp Allergy. 2011; 41(6):801-810. [PubMed: 21255140]

11. Lai Y, Oslund RC, Bollinger JG, et al. Eosinophil cysteinyl leukotriene synthesis mediated by exogenous secreted phospholipase A2 group X. J Biol Chem. 2010; 285(53):41491-41500. [PubMed: 20974857]

12. Sokolowska M, Stefanska J, Wodz-Naskiewicz K, et al. Cytosolic phospholipase A2 group IVA is overexpressed in patients with persistent asthma and regulated by the promoter microsatellites. $\mathrm{J}$ Allergy Clin Immunol. 2010; 125(6):1393-1395. [PubMed: 20392485]

13. Vadas P, Gold M, Perelman B, et al. Platelet-activating factor, PAF acetylhydrolase, and severe anaphylaxis. N Engl J Med. 2008; 358(1):28-35. [PubMed: 18172172]

14. Smith WL, Urade Y, Jakobsson PJ. Enzymes of the cyclooxygenase pathways of prostanoid biosynthesis. Chem Rev. 2011; 111(10):5821-5865. [PubMed: 21942677]

15. Kang YJ, Mbonye UR, Delong CJ, et al. Regulation of intracellular cyclooxygenase levels by gene transcription and protein degradation. Prog Lipid Res. 2007; 46(2):108-125. [PubMed: 17316818]

16. Ferguson S, Hebert RL, Laneuville O. NS-398 upregulates constitutive cyclooxygenase-2 expression in the M-1 cortical collecting duct cell line. J Am Soc Nephrol. 1999; 10(11):22612271. [PubMed: 10541284]

17. Sorli CH, Zhang HJ, Armstrong MB, et al. Basal expression of cyclooxygenase- 2 and nuclear factor-interleukin 6 are dominant and coordinately regulated by interleukin 1 in the pancreatic islet. Proc Natl Acad Sci U S A. 1998; 95(4):1788-1793. [PubMed: 9465095]

18. Soslow RA, Dannenberg AJ, Rush D, et al. COX-2 is expressed in human pulmonary, colonic, and mammary tumors. Cancer. 2000; 89(12):2637-2645. [PubMed: 11135226]

19. Fitzgerald GA. Coxibs and cardiovascular disease. N Engl J Med. 2004; 351(17):1709-1711. [PubMed: 15470192]

20. Sousa A, Pfister R, Christie PE, et al. Enhanced expression of cyclo-oxygenase isoenzyme 2 (COX-2) in asthmatic airways and its cellular distribution in aspirin-sensitive asthma. Thorax. 1997; 52(11):940-945. [PubMed: 9487340]

21. Demoly P, Jaffuel D, Lequeux N, et al. Prostaglandin H synthase 1 and 2 immunoreactivities in the bronchial mucosa of asthmatics. Am J Respir Crit Care Med. 1997; 155(2):670-675. [PubMed: 9032211]

22. Redington AE, Meng QH, Springall DR, et al. Increased expression of inducible nitric oxide synthase and cyclo-oxygenase- 2 in the airway epithelium of asthmatic subjects and regulation by corticosteroid treatment. Thorax. 2001; 56(5):351-357. [PubMed: 11312402]

23. Cho W, Kim Y, Jeoung DI, et al. IL-4 and IL-13 suppress prostaglandins production in human follicular dendritic cells by repressing COX-2 and mPGES-1 expression through JAK1 and STAT6. Mol Immunol. 2011; 48(6-7):966-972. [PubMed: 21277633]

24. Aksoy MO, Li X, Borenstein M, et al. Effects of topical corticosteroids on inflammatory mediatorinduced eicosanoid release by human airway epithelial cells. J Allergy Clin Immunol. 1999; 103(6):1081-1091. [PubMed: 10359890]

25. Pujols L, Benitez P, Alobid I, et al. Glucocorticoid therapy increases COX-2 gene expression in nasal polyps in vivo. Eur Respir J. 2009; 33(3):502-508. [PubMed: 19251796]

26. Ebbens FA, Maldonado M, de Groot EJ, et al. Topical glucocorticoids downregulate COX-1 positive cells in nasal polyps. Allergy. 2009; 64(1):96-103. [PubMed: 19132974]

27. Iniguez MA, Punzon C, Fresno M. Induction of cyclooxygenase- 2 on activated T lymphocytes: regulation of T cell activation by cyclooxygenase-2 inhibitors. J Immunol. 1999; 163(1):111-119. [PubMed: 10384106]

28. Kang YJ, Mbonye UR, Delong CJ, et al. Regulation of intracellular cyclooxygenase levels by gene transcription and protein degradation. Prog Lipid Res. 2007

29. Liu MC, Bleecker ER, Lichtenstein LM, et al. Evidence for elevated levels of histamine, prostaglandin D2, and other bronchoconstricting prostaglandins in the airways of subjects with mild asthma. Am Rev Respir Dis. 1990; 142(1):126-132. [PubMed: 2368958] 
30. Liu MC, Hubbard WC, Proud D, et al. Immediate and late inflammatory responses to ragweed antigen challenge of the peripheral airways in allergic asthmatics. Cellular, mediator, and permeability changes. Am Rev Respir Dis. 1991; 144(1):51-58. [PubMed: 2064141]

31. Liu MC, Proud D, Lichtenstein LM, et al. Effects of prednisone on the cellular responses and release of cytokines and mediators after segmental allergen challenge of asthmatic subjects. J Allergy Clin Immunol. 2001; 108(1):29-38. [PubMed: 11447379]

32. Fish JE, Ankin MG, Adkinson NF Jr, et al. Indomethacin modification of immediate-type immunologic airway responses in allergic asthmatic and non-asthmatic subjects: evidence for altered arachidonic acid metabolism in asthma. Am Rev Respir Dis. 1981; 123(6):609-614. [PubMed: 7271054]

33. Kirby JG, Hargreave FE, Cockcroft DW, et al. Effect of indomethacin on allergen-induced asthmatic responses. J Appl Physiol. 1989; 66(2):578-583. [PubMed: 2496075]

34. Sladek K, Dworski R, Fitzgerald GA, et al. Allergen-stimulated release of thromboxane A2 and leukotriene E4 in humans. Effect of indomethacin. Am Rev Respir Dis. 1990; 141(6):1441-1445. [PubMed: 2161626]

35. O'Byrne PM, Jones GL. The effect of indomethacin on exercise-induced bronchoconstriction and refractoriness after exercise. Am Rev Respir Dis. 1986; 134(1):69-72. [PubMed: 3729164]

36. Carey MA, Germolec DR, Bradbury JA, et al. Accentuated T helper type 2 airway response after allergen challenge in cyclooxygenase-1-/- but not cyclooxygenase-2-/- mice. Am J Respir Crit Care Med. 2003; 167(11):1509-1515. [PubMed: 12626351]

37. Zeldin DC, Wohlford-Lenane C, Chulada P, et al. Airway inflammation and responsiveness in prostaglandin $\mathrm{H}$ synthase-deficient mice exposed to bacterial lipopolysaccharide. Am J Respir Cell Mol Biol. 2001; 25(4):457-465. [PubMed: 11694451]

38. Card JW, Carey MA, Bradbury JA, et al. Cyclooxygenase-1 overexpression decreases Basal airway responsiveness but not allergic inflammation. J Immunol. 2006; 177(7):4785-4793. [PubMed: 16982919]

39. Nakata J, Kondo M, Tamaoki J, et al. Augmentation of allergic inflammation in the airways of cyclooxygenase-2-deficient mice. Respirology. 2005; 10(2):149-156. [PubMed: 15823178]

40. Peebles RS Jr, Dworski R, Collins RD, et al. Cyclooxygenase inhibition increases interleukin 5 and interleukin 13 production and airway hyperresponsiveness in allergic mice. Am J Respir Crit Care Med. 2000; 162:676-681. [PubMed: 10934105]

41. Peebles RS Jr, Hashimoto K, Sheller JR, et al. Allergen-induced airway hyperresponsiveness mediated by cyclooxygenase inhibition is not dependent on 5-lipoxygenase or IL-5, but is IL-13 dependent. J Immunol. 2005; 175(12):8253-8259. [PubMed: 16339565]

42. Hashimoto K, Sheller JR, Morrow JD, et al. Cyclooxygenase inhibition augments allergic inflammation through CD4-dependent, STAT6-independent mechanisms. J Immunol. 2005; 174(1):525-532. [PubMed: 15611279]

43. Peebles RS Jr, Hashimoto K, Morrow JD, et al. Selective cyclooxygenase-1 and -2 inhibitors each increase allergic inflammation and airway hyperresponsiveness in mice. Am J Respir Crit Care Med. 2002; 165(8):1154-1160. [PubMed: 11956061]

44. Laouini D, Elkhal A, Yalcindag A, et al. COX-2 inhibition enhances the TH2 immune response to epicutaneous sensitization. J Allergy Clin Immunol. 2005; 116(2):390-396. [PubMed: 16083795]

45. Oguma T, Asano K, Shiomi T, et al. Cyclooxygenase-2 expression during allergic inflammation in guinea-pig lungs. Am J Respir Crit Care Med. 2002; 165(3):382-386. [PubMed: 11818325]

46. Selg E, Lastbom L, Ryrfeldt A, et al. Effects of selective and non-selective COX inhibitors on antigen-induced release of prostanoid mediators and bronchoconstriction in the isolated perfused and ventilated guinea pig lung. Prostaglandins Leukot Essent Fatty Acids. 2008; 78(2):89-97. [PubMed: 18294831]

47. Safholm J, Dahlen SE, Delin I, et al. PGE2 maintains the tone of the guinea pig trachea through a balance between activation of contractile EP1 receptors and relaxant EP2 receptors. Br J Pharmacol. 2013; 168(4):794-806. [PubMed: 22934927]

48. Martin TR, Gerard NP, Galli SJ, et al. Pulmonary responses to bronchoconstrictor agonists in the mouse. Journal of Applied Physiology. 1988; 64(6):2318-2323. [PubMed: 2457008] 
49. Luna-Gomes T, Magalhaes KG, Mesquita-Santos FP, et al. Eosinophils as a novel cell source of prostaglandin D2: autocrine role in allergic inflammation. J Immunol. 2011; 187(12):6518-6526. [PubMed: 22102725]

50. Hirai H, Tanaka K, Yoshie O, et al. Prostaglandin D2 Selectively Induces Chemotaxis in T Helper Type 2 Cells, Eosinophils, and Basophils via Seven-Transmembrane Receptor CRTH2. J Exp Med. 2001; 193(2):255-262. [PubMed: 11208866]

51. Sugimoto H, Shichijo M, Okano M, et al. CRTH2-specific binding characteristics of $[3 \mathrm{H}]$ ramatroban and its effects on PGD2-, 15-deoxy-Delta12, 14- Eur J Pharmacol. 2005; 524(13):30-37. [PubMed: 16256979]

52. Mutalithas K, Guillen C, Day C, et al. CRTH2 expression on T cells in asthma. Clin Exp Immunol. 2010; 161(1):34-40. [PubMed: 20491797]

53. Johnston SL, Freezer NJ, Ritter W, et al. Prostaglandin D2-induced bronchoconstriction is mediated only in part by the thromboxane prostanoid receptor. Eur Respir J. 1995; 8(3):411-415. [PubMed: 7789486]

54. Larsson AK, Hagfjard A, Dahlen SE, et al. Prostaglandin D(2) induces contractions through activation of TP receptors in peripheral lung tissue from the guinea pig. Eur J Pharmacol. 2011; 669(1-3):136-142. [PubMed: 21872585]

55. Murray M, Webb MS, O'Callaghan C, et al. Respiratory status and allergy after bronchiolitis. Archives of Disease in Childhood. 1992; 67(4):482-487. [PubMed: 1580676]

56. Naclerio RM, Meier HL, Kagey-Sobotka A, et al. Mediator release after nasal airway challenge with allergen. Am Rev Respir Dis. 1983; 128(4):597-602. [PubMed: 6354022]

57. Proud D, Sweet J, Stein P, et al. Inflammatory mediator release on conjunctival provocation of allergic subjects with allergen. J Allergy Clin Immunol. 1990; 85(5):896-905. [PubMed: 1692049]

58. Charlesworth EN, Kagey-Sobotka A, Schleimer RP, et al. Prednisone inhibits the appearance of inflammatory mediators and the influx of eosinophils and basophils associated with the cutaneous late- phase response to allergen. J Immunol. 1991; 146(2):671-676. [PubMed: 1702812]

59. Daham K, Song WL, Lawson JA, et al. Effects of celecoxib on major prostaglandins in asthma. Clin Exp Allergy. 2011; 41(1):36-45. [PubMed: 20880055]

60. Johnston SL, Freezer NJ, Ritter W, et al. Prostaglandin D2-induced bronchoconstriction is mediated only in part by the thromboxane prostanoid receptor. Eur Respir J. 1995; 8(3):411-415. [PubMed: 7789486]

61. Doyle WJ, Boehm S, Skoner DP. Physiologic responses to intranasal dose-response challenges with histamine, methacholine, bradykinin, and prostaglandin in adult volunteers with and without nasal allergy. J Allergy Clin Immunol. 1990; 86(6 Pt 1):924-935. [PubMed: 2262647]

62. Flower RJ, Harvey EA, Kingston WP. Inflammatory effects of prostaglandin D2 in rat and human skin. Br J Pharmacol. 1976; 56(2):229-233. [PubMed: 1252671]

63. Woodward DF, Hawley SB, Williams LS, et al. Studies on the ocular pharmacology of prostaglandin D2. Invest Ophthalmol Vis Sci. 1990; 31(1):138-146. [PubMed: 2298534]

64. Emery DL, Djokic TD, Graf PD, et al. Prostaglandin D2 causes accumulation of eosinophils in the lumen of the dog trachea. J Appl Physiol. 1989; 67(3):959-962. [PubMed: 2793725]

65. Monneret G, Gravel S, Diamond M, et al. Prostaglandin D2 is a potent chemoattractant for human eosinophils that acts via a novel DP receptor. Blood. 2001; 98(6):1942-1948. [PubMed: 11535533]

66. Beasley RC, Featherstone RL, Church MK, et al. Effect of a thromboxane receptor antagonist on PGD2- and allergen-induced bronchoconstriction. J Appl Physiol. 1989; 66(4):1685-1693. [PubMed: 2525122]

67. Barnes N, Pavord I, Chuchalin A, et al. A randomized, double-blind, placebo-controlled study of the CRTH2 antagonist OC000459 in moderate persistent asthma. Clin Exp Allergy. 2012; 42(1): 38-48. [PubMed: 21762224]

68. Matsuoka T, Hirata M, Tanaka H, et al. Prostaglandin D2 as a mediator of allergic asthma. Science. 2000; 287(5460):2013-2017. [PubMed: 10720327]

69. Fujitani Y, Kanaoka Y, Aritake K, et al. Pronounced eosinophilic lung inflammation and Th2 cytokine release in human lipocalin-type prostaglandin D synthase transgenic mice. J Immunol. 2002; 168(1):443-449. [PubMed: 11751991] 
70. Honda K, Arima M, Cheng G, et al. Prostaglandin D2 reinforces Th2 type inflammatory responses of airways to low-dose antigen through bronchial expression of macrophage-derived chemokine. J Exp Med. 2003; 198(4):533-543. [PubMed: 12925672]

71. Hammad H, de Heer HJ, Soullie T, et al. Prostaglandin D2 inhibits airway dendritic cell migration and function in steady state conditions by selective activation of the D prostanoid receptor 1 . $\mathrm{J}$ Immunol. 2003; 171(8):3936-3940. [PubMed: 14530310]

72. Hammad H, Kool M, Soullie T, et al. Activation of the D prostanoid 1 receptor suppresses asthma by modulation of lung dendritic cell function and induction of regulatory T cells. J Exp Med. 2007; 204(2):357-367. [PubMed: 17283205]

73. Bain G, Lorrain DS, Stebbins KJ, et al. Pharmacology of AM211, a potent and selective prostaglandin D2 receptor type 2 antagonist that is active in animal models of allergic inflammation. J Pharmacol Exp Ther. 2011; 338(1):290-301. [PubMed: 21487069]

74. Gervais FG, Sawyer N, Stocco R, et al. Pharmacological characterization of MK-7246, a potent and selective CRTH2 (chemoattractant receptor-homologous molecule expressed on T-helper type 2 cells) antagonist. Mol Pharmacol. 2011; 79(1):69-76. [PubMed: 20943773]

75. Crosignani S, Pretre A, Jorand-Lebrun C, et al. Discovery of potent, selective, and orally bioavailable alkynylphenoxyacetic acid CRTH2 (DP2) receptor antagonists for the treatment of allergic inflammatory diseases. J Med Chem. 2011; 54(20):7299-7317. [PubMed: 21916510]

76. Ueno N, Taketomi Y, Yamamoto K, et al. Analysis of two major intracellular phospholipases A(2) (PLA(2)) in mast cells reveals crucial contribution of cytosolic PLA(2)alpha, not Ca(2+)independent PLA(2)beta, to lipid mobilization in proximal mast cells and distal fibroblasts. J Biol Chem. 2011; 286(43):37249-37263. [PubMed: 21880721]

77. Tanioka T, Nakatani Y, Semmyo N, et al. Molecular identification of cytosolic prostaglandin E2 synthase that is functionally coupled with cyclooxygenase-1 in immediate prostaglandin E2 biosynthesis. J Biol Chem. 2000; 275(42):32775-32782. [PubMed: 10922363]

78. Kahnt AS, Rorsch F, Diehl O, et al. Cysteinyl leukotriene-receptor-1 antagonists interfere with PGE2 synthesis by inhibiting mPGES-1 activity. Biochem Pharmacol. 2013; 86(2):286-296. [PubMed: 23684692]

79. Park JY, Pillinger MH, Abramson SB. Prostaglandin E2 synthesis and secretion: the role of PGE2 synthases. Clin Immunol. 2006; 119(3):229-240. [PubMed: 16540375]

80. Kalinski P. Regulation of immune responses by prostaglandin E2. J Immunol. 2012; 188(1):21-28. [PubMed: 22187483]

81. Coleman RA, Smith WL, Narumiya S. International Union of Pharmacology classification of prostanoid receptors: properties, distribution, and structure of the receptors and their subtypes [Review] [242 refs]. Pharmacological Reviews. 1994; 46(2):205-229. [PubMed: 7938166]

82. Breyer RM, Bagdassarian CK, Myers SA, et al. Prostanoid receptors: subtypes and signaling. Annu Rev Pharmacol Toxicol. 2001; 41:661-690. [PubMed: 11264472]

83. An S, Yang J, Xia M, et al. Cloning and expression of the EP2 subtype of human receptors for prostaglandin E2. Biochemical \& Biophysical Research Communications. 1993; 197(1):263-270. [PubMed: 8250933]

84. Adam M, Boie Y, Rushmore TH, et al. Cloning and expression of three isoforms of the human EP3 prostanoid receptor. FEBS Letters. 1994; 338(2):170-174. [PubMed: 8307176]

85. Churchill L, Chilton FH, Resau JH, et al. Cyclooxygenase metabolism of endogenous arachidonic acid by cultured human tracheal epithelial cells. Am Rev Respir Dis. 1989; 140(2):449-459. [PubMed: 2504090]

86. Delamere F, Holland E, Patel S, et al. Production of PGE2 by bovine cultured airway smooth muscle cells and its inhibition by cyclo-oxygenase inhibitors. Br J Pharmacol. 1994; 111(4):983988. [PubMed: 8032626]

87. Pavord ID, Tattersfield AE. Bronchoprotective role for endogenous prostaglandin E2. Lancet. 1995; 345(8947):436-438. [PubMed: 7853958]

88. Barnett K, Jacoby DB, Nadel JA, et al. The effects of epithelial cell supernatant on contractions of isolated canine tracheal smooth muscle. Am Rev Respir Dis. 1988; 138(4):780-783. [PubMed: 3202451] 
89. Schmidt LM, Belvisi MG, Bode KA, et al. Bronchial epithelial cell-derived prostaglandin E2 dampens the reactivity of dendritic cells. J Immunol. 2011; 186(4):2095-2105. [PubMed: 21228345]

90. Aggarwal S, Moodley YP, Thompson PJ, et al. Prostaglandin E2 and cysteinyl leukotriene concentrations in sputum: association with asthma severity and eosinophilic inflammation. Clin Exp Allergy. 2010; 40(1):85-93. [PubMed: 19895589]

91. Pavord ID, Ward R, Woltmann G, et al. Induced sputum eicosanoid concentrations in asthma. Am J Respir Crit Care Med. 1999; 160(6):1905-1909. [PubMed: 10588604]

92. Gauvreau GM, Watson RM, O’Byrne PM. Protective effects of inhaled PGE2 on allergen-induced airway responses and airway inflammation. American Journal of Respiratory \& Critical Care Medicine. 1999; 159(1):31-36. [PubMed: 9872814]

93. Pavord ID, Wong CS, Williams J, et al. Effect of inhaled prostaglandin E2 on allergen-induced asthma. Am Rev Respir Dis. 1993; 148(1):87-90. [PubMed: 8317820]

94. Melillo E, Woolley KL, Manning PJ, et al. Effect of inhaled PGE2 on exercise-induced bronchoconstriction in asthmatic subjects. Am J Respir Crit Care Med. 1994; 149(5):1138-1141. [PubMed: 8173753]

95. Sestini P, Armetti L, Gambaro G, et al. Inhaled PGE2 prevents aspirin-induced bronchoconstriction and urinary LTE4 excretion in aspirin-sensitive asthma. Am J Respir Crit Care Med. 1996; 153(2):572-575. [PubMed: 8564100]

96. Hartert TV, Dworski RT, Mellen BG, et al. Prostaglandin E(2) decreases allergen-stimulated release of prostaglandin $\mathrm{D}(2)$ in airways of subjects with asthma. Am J Respir Crit Care Med. 2000; 162(2 Pt 1):637-640. [PubMed: 10934099]

97. Buckley J, Birrell MA, Maher SA, et al. EP4 receptor as a new target for bronchodilator therapy. Thorax. 2011; 66(12):1029-1035. [PubMed: 21606476]

98. Maher SA, Birrell MA, Belvisi MG. Prostaglandin E2 mediates cough via the EP3 receptor: implications for future disease therapy. Am J Respir Crit Care Med. 2009; 180(10):923-928. [PubMed: 19729667]

99. Goncharova EA, Goncharov DA, Zhao $\mathrm{H}$, et al. beta2-adrenergic receptor agonists modulate human airway smooth muscle cell migration via vasodilator-stimulated phosphoprotein. Am J Respir Cell Mol Biol. 2012; 46(1):48-54. [PubMed: 22210825]

100. Yan H, Deshpande DA, Misior AM, et al. Anti-mitogenic effects of beta-agonists and PGE2 on airway smooth muscle are PKA dependent. FASEB J. 2011; 25(1):389-397. [PubMed: 20805374]

101. Wasiak W, Szmidt M. A six week double blind, placebo controlled, crossover study of the effect of misoprostol in the treatment of aspirin sensitive asthma. Thorax. 1999; 54(10):900-904. [PubMed: 10491452]

102. Harmanci E, Ozakyol A, Ozdemir N, et al. Misoprostol has no favorable effect on bronchial hyperresponsiveness in mild asthmatics. Allerg Immunol (Paris). 1998; 30(9):298-300. [PubMed: 9887990]

103. Pawlotsky JM, Ruszniewski P, Reyl-Desmars F, et al. Effects of PGE2, misoprostol, and enprostil on guinea pig enterocyte adenylate cyclase. Clinical implications Dig Dis Sci. 1993; 38(2):316320.

104. Betz M, Fox BS. Prostaglandin E2 inhibits production of Th1 lymphokines but not of Th2 lymphokines. Journal of Immunology. 1991; 146(1):108-113.

105. Snijdewint FG, Kalinski P, Wierenga EA, et al. Prostaglandin E2 differentially modulates cytokine secretion profiles of human T helper lymphocytes. Journal of Immunology. 1993; 150(12):5321-5329.

106. Katamura K, Shintaku N, Yamauchi Y, et al. Prostaglandin E2 at priming of naive CD4+ T cells inhibits acquisition of ability to produce IFN-gamma and IL-2, but not IL- 4 and IL-5. Journal of Immunology. 1995; 155(10):4604-4612.

107. Hilkens CM, Vermeulen H, van Neerven RJ, et al. Differential modulation of T helper type 1 (Th1) and T helper type 2 (Th2) cytokine secretion by prostaglandin E2 critically depends on interleukin-2. European Journal of Immunology. 1995; 25(1):59-63. [PubMed: 7843254] 
108. Vieira PL, de Jong EC, Wierenga EA, et al. Development of Th1-inducing capacity in myeloid dendritic cells requires environmental instruction. Journal of Immunology. 2000; 164(9):45074512.

109. Chizzolini C, Chicheportiche R, Alvarez M, et al. Prostaglandin E2 synergistically with interleukin-23 favors human Th17 expansion. Blood. 2008; 112(9):3696-3703. [PubMed: 18698005]

110. Peacock CD, Misso NL, Watkins DN, et al. PGE 2 and dibutyryl cyclic adenosine monophosphate prolong eosinophil survival in vitro. J Allergy Clin Immunol. 1999; 104(1):153162. [PubMed: 10400853]

111. Kita H, Abu-Ghazaleh RI, Gleich GJ, et al. Regulation of Ig-induced eosinophil degranulation by adenosine $3^{\prime}, 5^{\prime}$-cyclic monophosphate. J Immunol. 1991; 146(8):2712-2718. [PubMed: 1707917]

112. Teixeira MM, al Rashed S, Rossi AG, et al. Characterization of the prostanoid receptors mediating inhibition of PAF-induced aggregation of guinea-pig eosinophils. Br J Pharmacol. 1997; 121(1):77-82. [PubMed: 9146890]

113. Sturm EM, Schratl P, Schuligoi R, et al. Prostaglandin E2 inhibits eosinophil trafficking through E-prostanoid 2 receptors. J Immunol. 2008; 181(10):7273-7283. [PubMed: 18981149]

114. Lazzeri N, Belvisi MG, Patel HJ, et al. Effects of prostaglandin E2 and cAMP elevating drugs on GM-CSF release by cultured human airway smooth muscle cells. Relevance to asthma therapy. Am J Respir Cell Mol Biol. 2001; 24(1):44-48. [PubMed: 11152649]

115. Gomi K, Zhu FG, Marshall JS. Prostaglandin E2 selectively enhances the IgE-mediated production of IL- 6 and granulocyte-macrophage colony-stimulating factor by mast cells through an EP1/EP3-dependent mechanism. J Immunol. 2000; 165(11):6545-6552. [PubMed: 11086097]

116. Hogaboam CM, Bissonnette EY, Chin BC, et al. Prostaglandins inhibit inflammatory mediator release from rat mast cells. Gastroenterology. 1993; 104(1):122-129. [PubMed: 7678236]

117. Kaliner M, Austen KF. Cyclic AMP, ATP, and reversed anaphylactic histamine release from rat mast cells. J Immunol. 1974; 112(2):664-674. [PubMed: 4130694]

118. Peachell PT, MacGlashan DW Jr, Lichtenstein LM, et al. Regulation of human basophil and lung mast cell function by cyclic adenosine monophosphate. J Immunol. 1988; 140(2):571-579. [PubMed: 2447182]

119. Leal-Berumen I, O’Byrne P, Gupta A, et al. Prostanoid enhancement of interleukin-6 production by rat peritoneal mast cells. J Immunol. 1995; 154(9):4759-4767. [PubMed: 7536779]

120. Nishigaki N, Negishi M, Honda A, et al. Identification of prostaglandin E receptor 'EP2' cloned from mastocytoma cells EP4 subtype. FEBS Lett. 1995; 364(3):339-341. [PubMed: 7758593]

121. Feng C, Beller EM, Bagga S, et al. Human mast cells express multiple EP receptors for prostaglandin E2 that differentially modulate activation responses. Blood. 2006; 107(8):32433250. [PubMed: 16357326]

122. Mastalerz L, Sanak M, Gawlewicz-Mroczka A, et al. Prostaglandin E2 systemic production in patients with asthma with and without aspirin hypersensitivity. Thorax. 2008; 63(1):27-34. [PubMed: 17584993]

123. Szczeklik A, Mastalerz L, Nizankowska E, et al. Protective and bronchodilator effects of prostaglandin E and salbutamol in aspirin-induced asthma. Am J Respir Crit Care Med. 1996; 153(2):567-571. [PubMed: 8564099]

124. Gyllfors P, Bochenek G, Overholt J, et al. Biochemical and clinical evidence that aspirinintolerant asthmatic subjects tolerate the cyclooxygenase 2-selective analgetic drug celecoxib. J Allergy Clin Immunol. 2003; 111(5):1116-1121. [PubMed: 12743579]

125. Kowalski ML, Pawliczak R, Wozniak J, et al. Differential metabolism of arachidonic acid in nasal polyp epithelial cells cultured from aspirin-sensitive and aspirin-tolerant patients. Am J Respir Crit Care Med. 2000; 161(2 Pt 1):391-398. [PubMed: 10673176]

126. Perez-Novo CA, Watelet JB, Claeys C, et al. Prostaglandin, leukotriene, and lipoxin balance in chronic rhinosinusitis with and without nasal polyposis. J Allergy Clin Immunol. 2005; 115(6): 1189-1196. [PubMed: 15940133] 
127. Pierzchalska M, Szabo Z, Sanak M, et al. Deficient prostaglandin E2 production by bronchial fibroblasts of asthmatic patients, with special reference to aspirin-induced asthma. J Allergy Clin Immunol. 2003; 111(5):1041-1048. [PubMed: 12743569]

128. Roca-Ferrer J, Garcia-Garcia FJ, Pereda J, et al. Reduced expression of COXs and production of prostaglandin $\mathrm{E}(2)$ in patients with nasal polyps with or without aspirin-intolerant asthma. $\mathbf{J}$ Allergy Clin Immunol. 2011; 128(1):66-72. [PubMed: 21397936]

129. Adamusiak AM, Stasikowska-Kanicka O, Lewandowska-Polak A, et al. Expression of arachidonate metabolism enzymes and receptors in nasal polyps of aspirin-hypersensitive asthmatics. Int Arch Allergy Immunol. 2012; 157(4):354-362. [PubMed: 22123288]

130. Corrigan CJ, Napoli RL, Meng Q, et al. Reduced expression of the prostaglandin E2 receptor Eprostanoid 2 on bronchial mucosal leukocytes in patients with aspirin-sensitive asthma. J Allergy Clin Immunol. 2012; 129(6):1636-1646. [PubMed: 22418066]

131. Ying S, Meng Q, Scadding G, et al. Aspirin-sensitive rhinosinusitis is associated with reduced Eprostanoid 2 receptor expression on nasal mucosal inflammatory cells. J Allergy Clin Immunol. 2006; 117(2):312-318. [PubMed: 16461132]

132. Jinnai N, Sakagami T, Sekigawa T, et al. Polymorphisms in the prostaglandin E2 receptor subtype 2 gene confer susceptibility to aspirin-intolerant asthma: a candidate gene approach. Hum Mol Genet. 2004; 13(24):3203-3217. [PubMed: 15496426]

133. Kim SH, Kim YK, Park HW, et al. Association between polymorphisms in prostanoid receptor genes and aspirin-intolerant asthma. Pharmacogenet Genomics. 2007; 17(4):295-304. [PubMed: 17496729]

134. Kunikata T, Yamane H, Segi E, et al. Suppression of allergic inflammation by the prostaglandin E receptor subtype EP3. Nat Immunol. 2005; 6(5):524-531. [PubMed: 15806106]

135. Herrerias A, Torres R, Serra M, et al. Subcutaneous prostaglandin E(2) restrains airway mast cell activity in vivo and reduces lung eosinophilia and $\mathrm{Th}(2)$ cytokine overproduction in house dust mite-sensitive mice. Int Arch Allergy Immunol. 2009; 149(4):323-332. [PubMed: 19295236]

136. Kuehn HS, Jung MY, Beaven MA, et al. Prostaglandin E2 activates and utilizes mTORC2 as a central signaling locus for the regulation of mast cell chemotaxis and mediator release. J Biol Chem. 2011; 286(1):391-402. [PubMed: 20980255]

137. Weller CL, Collington SJ, Hartnell A, et al. Chemotactic action of prostaglandin E2 on mouse mast cells acting via the PGE2 receptor 3. Proc Natl Acad Sci U S A. 2007; 104(28):1171211717. [PubMed: 17606905]

138. Stumm CL, Wettlaufer SH, Jancar S, et al. Airway remodeling in murine asthma correlates with a defect in PGE2 synthesis by lung fibroblasts. Am J Physiol Lung Cell Mol Physiol. 2011; 301(5):L636-L644. [PubMed: 21873451]

139. Lundequist A, Nallamshetty SN, Xing W, et al. Prostaglandin E(2) exerts homeostatic regulation of pulmonary vascular remodeling in allergic airway inflammation. J Immunol. 2010; 184(1): 433-441. [PubMed: 20028661]

140. Hartney JM, Coggins KG, Tilley SL, et al. Prostaglandin E2 protects lower airways against bronchoconstriction. Am J Physiol Lung Cell Mol Physiol. 2006; 290(1):L105-L113. [PubMed: 16113047]

141. Sheller JR, Mitchell D, Meyrick B, et al. EP(2) receptor mediates bronchodilation by PGE(2) in mice. J Appl Physiol. 2000; 88(6):2214-2218. [PubMed: 10846038]

142. Tilley SL, Hartney JM, Erikson CJ, et al. Receptors and pathways mediating the effects of prostaglandin E2 on airway tone. Am J Physiol Lung Cell Mol Physiol. 2003; 284(4):L599_ L606. [PubMed: 12618422]

143. Liu T, Laidlaw TM, Katz HR, et al. Prostaglandin E2 deficiency causes a phenotype of aspirin sensitivity that depends on platelets and cysteinyl leukotrienes. Proc Natl Acad Sci U S A. 2013; 110(42):16987-16992. [PubMed: 24085850]

144. Komoto J, Yamada T, Watanabe K, et al. Prostaglandin F2alpha formation from prostaglandin H2 by prostaglandin F synthase (PGFS): crystal structure of PGFS containing bimatoprost. Biochemistry. 2006; 45(7):1987-1996. [PubMed: 16475787] 
145. Suzuki-Yamamoto T, Nishizawa M, Fukui M, et al. cDNA cloning, expression and characterization of human prostaglandin F synthase. FEBS Lett. 1999; 462(3):335-340. [PubMed: 10622721]

146. Hata AN, Breyer RM. Pharmacology and signaling of prostaglandin receptors: multiple roles in inflammation and immune modulation. Pharmacol Ther. 2004; 103(2):147-166. [PubMed: 15369681]

147. Breyer MD, Breyer RM. G protein-coupled prostanoid receptors and the kidney. Annu Rev Physiol. 2001; 63:579-605. [PubMed: 11181968]

148. Mathe AA, Hedqvist P, Holmgren A, et al. Bronchial hyperreactivity to prostaglandin $\mathrm{F} 2$ and histamine in patients with asthma. Br Med J. 1973; 1(5847):193-196. [PubMed: 4686554]

149. Smith AP, Cuthbert MF. Prostaglandins and resistance to beta adrenoceptor stimulants. Br Med J. 1972; 2(806):166. [PubMed: 4401562]

150. Smith AP, Cuthbert MF, Dunlop LS. Effects of inhaled prostaglandins E1, E2, and F2alpha on the airway resistance of healthy and asthmatic man. Clin Sci Mol Med. 1975; 48(5):421-430. [PubMed: 1126133]

151. Kharitonov SA, Sapienza MA, Barnes PJ, et al. Prostaglandins E2 and F2alpha reduce exhaled nitric oxide in normal and asthmatic subjects irrespective of airway caliber changes. Am J Respir Crit Care Med. 1998; 158(5 Pt 1):1374-1378. [PubMed: 9817681]

152. Oga T, Matsuoka T, Yao C, et al. Prostaglandin F(2alpha) receptor signaling facilitates bleomycin-induced pulmonary fibrosis independently of transforming growth factor-beta. Nat Med. 2009; 15(12):1426-1430. [PubMed: 19966781]

153. Nakayama T. Prostacyclin analogues: prevention of cardiovascular diseases. Cardiovasc Hematol Agents Med Chem. 2006; 4(4):351-359. [PubMed: 17073611]

154. Breyer RM, Kennedy CR, Zhang Y, et al. Structure-function analyses of eicosanoid receptors. Physiologic and therapeutic implications. Ann N Y Acad Sci. 2000; 905:221-231. [PubMed: 10818456]

155. Zhou W, Hashimoto K, Goleniewska K, et al. Prostaglandin I2 analogs inhibit proinflammatory cytokine production and T cell stimulatory function of dendritic cells. J Immunol. 2007; 178(2): 702-710. [PubMed: 17202330]

156. Muller T, Durk T, Blumenthal B, et al. Iloprost has potent anti-inflammatory properties on human monocyte-derived dendritic cells. Clin Exp Allergy. 2010; 40(8):1214-1221. [PubMed: 20649610]

157. Narumiya S, Sugimoto Y, Ushikubi F. Prostanoid receptors: structures, properties, and functions. Physiol Rev. 1999; 79(4):1193-1226. [PubMed: 10508233]

158. Komhoff M, Lesener B, Nakao K, et al. Localization of the prostacyclin receptor in human kidney. Kidney Int. 1998; 54(6):1899-1908. [PubMed: 9853255]

159. Zhou W, Blackwell TS, Goleniewska K, et al. Prostaglandin I2 analogs inhibit Th1 and Th2 effector cytokine production by CD4 T cells. J Leukoc Biol. 2007; 81(3):809-817. [PubMed: 17135575]

160. Schulman ES, Newball HH, Demers LM, et al. Anaphylactic release of thromboxane A2, prostaglandin D2, and prostacyclin from human lung parenchyma. Am Rev Respir Dis. 1981; 124(4):402-406. [PubMed: 6170242]

161. Schulman ES, Adkinson NF Jr, Newball HH. Cyclooxygenase metabolites in human lung anaphylaxis: airway vs. parenchyma. J Appl Physiol. 1982; 53(3):589-595. [PubMed: 6813301]

162. Shephard EG, Malan L, Macfarlane CM, et al. Lung function and plasma levels of thromboxane B2, 6-ketoprostaglandin F1 alpha and beta-thromboglobulin in antigen-induced asthma before and after indomethacin pretreatment. Br J Clin Pharmacol. 1985; 19(4):459-470. [PubMed: 2581599]

163. Bianco S, Robuschi M, Grugni A, et al. Effect of prostacyclin on antigen induced immediate bronchoconstriction in asthmatic patients. Prostaglandins Med. 1979; 3(1):39-45. [PubMed: 399527]

164. Bianco S, Robuschi M, Ceserani R, et al. Effects of prostacyclin on aspecifically and specifically induced bronchoconstriction in asthmatic patients. Eur J Respir Dis Suppl. 1980; 106:81-87. [PubMed: 7009192] 
165. Hardy C, Robinson C, Lewis RA, et al. Airway and cardiovascular responses to inhaled prostacyclin in normal and asthmatic subjects. American Review of Respiratory Disease. 1985; 131(1):18-21. [PubMed: 2981491]

166. Nizankowska E, Czerniawska-Mysik G, Szczeklik A. Lack of effect of i.v. prostacyclin on aspirin-induced asthma. Eur J Respir Dis. 1986; 69(5):363-368. [PubMed: 3539632]

167. Hardy CC, Bradding P, Robinson C, et al. Bronchoconstrictor and antibronchoconstrictor properties of inhaled prostacyclin in asthma. J Appl Physiol. 1988; 64(4):1567-1574. [PubMed: 3288608]

168. Fujimura M, Ozawa S, Matsuda T. Effect of oral administration of a prostacyclin analog (OP-41483) on pulmonary function and bronchial responsiveness in stable asthmatic subjects. J Asthma. 1991; 28(6):419-424. [PubMed: 1744027]

169. Majeski E, Hoskins A, Dworski R, et al. Iloprost inhalation in mild asthma. J Asthma. 2012; 49(9):961-965. [PubMed: 23033807]

170. Takahashi Y, Tokuoka S, Masuda T, et al. Augmentation of allergic inflammation in prostanoid IP receptor deficient mice. Br J Pharmacol. 2002; 137(3):315-322. [PubMed: 12237250]

171. Nagao K, Tanaka H, Komai M, et al. Role of prostaglandin I 2 in airway remodeling induced by repeated allergen challenge in mice. Am J Respir Cell Mol Biol. 2003

172. Lovgren AK, Jania LA, Hartney JM, et al. COX-2-derived prostacyclin protects against bleomycin-induced pulmonary fibrosis. Am J Physiol Lung Cell Mol Physiol. 2006; 291(2):L144-L156. [PubMed: 16473862]

173. Zhou W, Dowell DR, Geraci MW, et al. PGI synthase overexpression protects against bleomycininduced mortality and is associated with increased Nqo 1 expression. Am J Physiol Lung Cell Mol Physiol. 2011; 301(4):L615-L622. [PubMed: 21764988]

174. Idzko M, Hammad H, van Nimwegen M, et al. Inhaled iloprost suppresses the cardinal features of asthma via inhibition of airway dendritic cell function. J Clin Invest. 2007; 117(2):464-472. [PubMed: 17273558]

175. Toki S, Goleniewska K, Huckabee MM, et al. PGI2 signaling inhibits antigen uptake and increases migration of immature dendritic cells. J Leukoc Biol. 2013

176. Boswell MG, Zhou W, Newcomb DC, et al. PGI2 as a regulator of CD4+ subset differentiation and function. Prostaglandins Other Lipid Mediat. 2011; 96(1-4):21-26. [PubMed: 21864703]

177. Dorris SL, Peebles RS Jr. PGI(2) as a Regulator of Inflammatory Diseases. Mediators Inflamm. 2012; 2012:926968. [PubMed: 22851816]

178. Whittle BJ, Moncada S. Pharmacological interactions between prostacyclin and thromboxanes. $\mathrm{Br}$ Med Bull. 1983; 39(3):232-238. [PubMed: 6313114]

179. Miyata A, Yokoyama C, Ihara H, et al. Characterization of the human gene (TBXAS1) encoding thromboxane synthase. Eur J Biochem. 1994; 224(2):273-279. [PubMed: 7925341]

180. Ruan KH. Advance in understanding the biosynthesis of prostacyclin and thromboxane A2 in the endoplasmic reticulum membrane via the cyclooxygenase pathway. Mini Rev Med Chem. 2004; 4(6):639-647. [PubMed: 15279598]

181. Roberts LJ, Sweetman BJ, Oates JA. Metabolism of thromboxane B2 in man. J Biol Chem. 1981; 256(16):8384-8393. [PubMed: 7263660]

182. Raychowdhury MK, Yukawa M, Collins LJ, et al. Alternative splicing produces a divergent cytoplasmic tail in the human endothelial thromboxane A2 receptor. J Biol Chem. 1994; 269(30): 19256-19261. [PubMed: 8034687]

183. Huang JS, Ramamurthy SK, Lin X, et al. Cell signalling through thromboxane A2 receptors. Cell Signal. 2004; 16(5):521-533. [PubMed: 14751539]

184. Hirata T, Ushikubi F, Kakizuka A, et al. Two thromboxane A2 receptor isoforms in human platelets. Opposite coupling to adenylyl cyclase with different sensitivity to Arg60 to Leu mutation. J Clin Invest. 1996; 97(4):949-956. [PubMed: 8613548]

185. Grosser T, Fries S, Fitzgerald GA. Biological basis for the cardiovascular consequences of COX-2 inhibition: therapeutic challenges and opportunities. J Clin Invest. 2006; 116(1):4-15. [PubMed: 16395396]

186. Roberts LJ, Sweetman BJ, Lewis RA, et al. Increased production of prostaglandin D2 in patients with systemic mastocytosis. N Engl J Med. 1980; 303(24):1400-1404. [PubMed: 6107852] 
187. Taylor IK, Ward PS, O'Shaughnessy KM, et al. Thromboxane A2 biosynthesis in acute asthma and after antigen challenge. Am Rev Respir Dis. 1991; 143(1):119-125. [PubMed: 1986668]

188. Lupinetti MD, Sheller JR, Catella F, et al. Thromboxane biosynthesis in allergen-induced bronchospasm. Evidence for platelet activation. Am Rev Respir Dis. 1989; 140(4):932-935. [PubMed: 2508524]

189. Seltzer J, Bigby BG, Stulbarg M, et al. O3-induced change in bronchial reactivity to methacholine and airway inflammation in humans. J Appl Physiol. 1986; 60(4):1321-1326. [PubMed: 3084448]

190. O’Byrne PM, Leikauf GD, Aizawa H, et al. Leukotriene B4 induces airway hyperresponsiveness in dogs. J Appl Physiol. 1985; 59(6):1941-1946. [PubMed: 3001017]

191. Aizawa H, Inoue H, Nakano H, et al. Effects of thromboxane A2 antagonist on airway hyperresponsiveness, exhaled nitric oxide, and induced sputum eosinophils in asthmatics. Prostaglandins Leukot. Essent Fatty Acids. 1998; 59(3):185-190.

192. Hoshino M, Sim J, Shimizu K, et al. Effect of AA-2414, a thromboxane A2 receptor antagonist, on airway inflammation in subjects with asthma. J Allergy Clin Immunol. 1999; 103(6):10541061. [PubMed: 10359886]

193. Shi H, Yokoyama A, Kohno N, et al. Effect of thromboxane A2 inhibitors on allergic pulmonary inflammation in mice. European Respiratory Journal. 1998; 11(3):624-629. [PubMed: 9596113]

194. Liu T, Laidlaw TM, Feng C, et al. Prostaglandin E2 deficiency uncovers a dominant role for thromboxane A2 in house dust mite-induced allergic pulmonary inflammation. Proc Natl Acad Sci U S A. 2012; 109(31):12692-12697. [PubMed: 22802632] 


\section{KEY ISSUES}

- COX inhibition, either by gene deletion or pharmacologic approach, augmented allergic inflammation in several animal models.

- $\quad \mathrm{PGD}_{2}$ is the major mast cell-derived prostanoid and is elaborated in nanogram quantities in these cells in response to IgE-mediated activation.

- Mouse studies suggest that signaling through DP augments allergic inflammation and a $\mathrm{DP}_{2}$ antagonist significantly improved both quality of life and night-time symptom score in a randomized, double-blind, placebocontrolled trial in humans with moderate-persistent asthma.

- $\mathrm{PGE}_{2}$ inhibits the cysteinyl leukotriene synthesis pathway and inhibition of $\mathrm{PGE}_{2}$ synthesis is a major pathogenic mechanism of aspirin exacerbated respiratory disease.

- $\mathrm{PGI}_{2}$ restrains allergic airway inflammation in mice by inhibiting dendritic cell activation of CD4+ Th2 cells, Th2 cell differentiation, and eosinophil migration.

- $\mathrm{TXA}_{2}$ is an inflammatory and bronchoconstrictive mediator in asthma.

- $\mathrm{PGF}_{2 \mathrm{a}}$ is a pro-fibrotic mediator in pulmonary fibrosis.

- Future research will continue to expand understanding of the molecular signaling pathways of prostaglandins and further identify therapeutic options in pulmonary disease. 


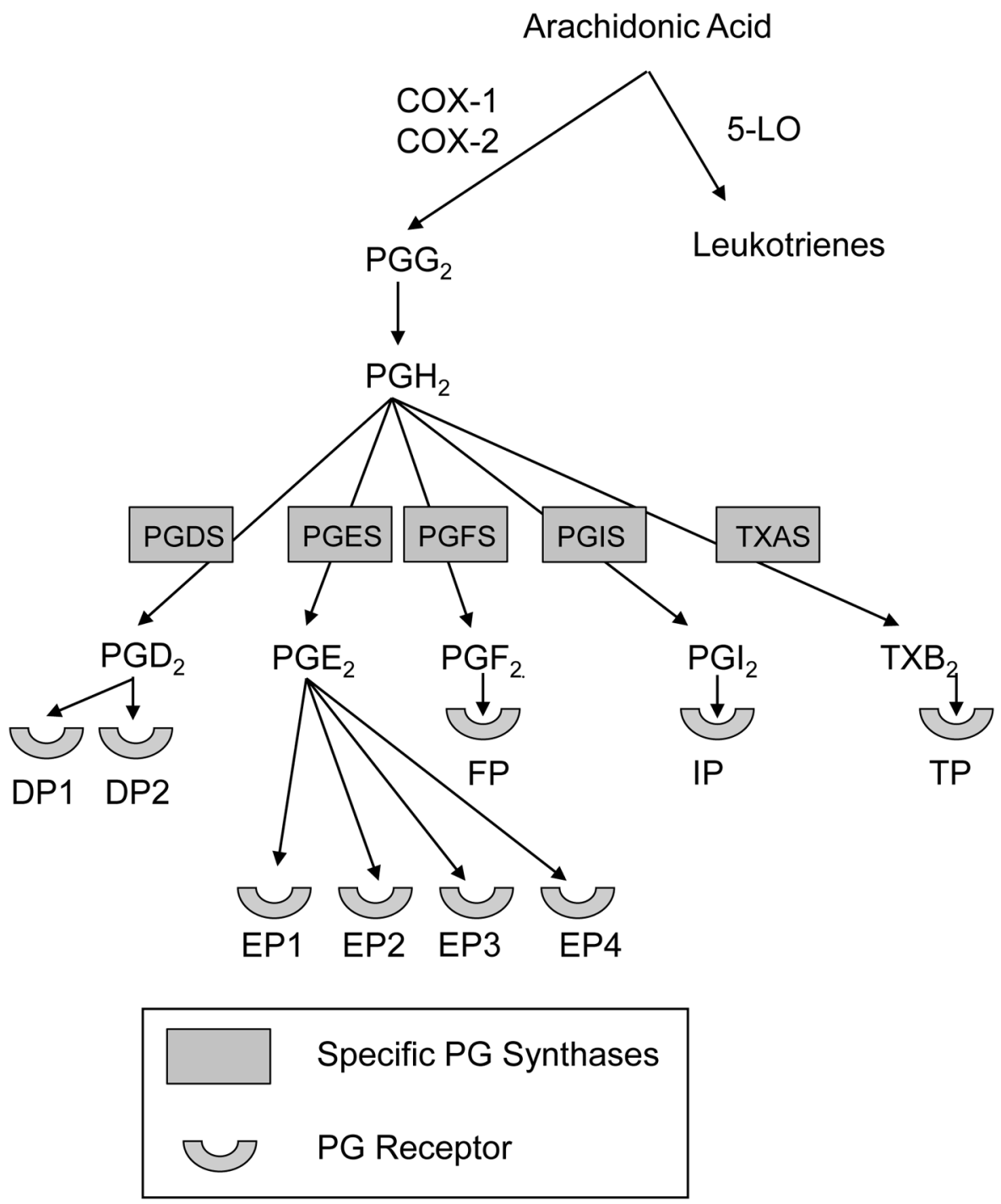

Figure 1.

Expert Rev Respir Med. Author manuscript; available in PMC 2016 February 01. 